ResearCh Article

Published February 13, 2019

\title{
HBV and HIV/HBV Infected Patients Have Distinct Immune Exhaustion and Apoptotic Serum Biomarker Profiles
}

\section{AUTHORS}

Mohamed Tarek M. Shata ${ }^{1}$, Enass A. Abdel-hameed ${ }^{1}$, Susan D. Rouster ${ }^{1}$, Li Yu ${ }^{2}$, Meina Liang ${ }^{3}$, Esther Song ${ }^{3}$, Mark T. Esser ${ }^{2}$, Norah Shire ${ }^{4}$, Kenneth E. Sherman ${ }^{1}$

\section{AFFILIATED INSTITUTIONS}

${ }^{1}$ Internal medicine; University of Cincinnati; Cincinnati, Ohio

${ }^{2}$ MedImmune; Gaithersburg, Maryland

${ }^{3}$ MedImmune; 121 Oyster Point Boulevard; South San Francisco, California

${ }^{4}$ AstraZeneca; Gaithersburg, Maryland

\section{CORRESPONDING AUTHOR}

DOI

Mohamed Tarek M. Shata

10.20411/pai.v4i1.267

Viral Immunology Laboratory, MSB 7255E

Department of Internal Medicine

Division of Digestive Diseases

231 Albert B. Sabin Way

University of Cincinnati Medical Center

Cincinnati, OH 45267-0595

Telephone: (513) 558-1714

\section{SUGGESTED CITATION}

Shata MTM, Abdel-hameed EA, Rouster SD, Yu L, Liang M, Song E, Esser MT, Shire N, Sherman KE. HBV and HIV/HBV infected subjects have distinct immune exhaustion and apoptotic serum biomarker profiles. Pathogens and Immunity. 2019;4(1):39-65. doi: 10.20411/pai.v4i1.267 


\section{ABSTRACT}

Background: Hepatitis B virus (HBV) infection is a leading cause of chronic hepatitis, liver cirrhosis, and hepatocellular carcinoma worldwide. Due to their shared routes of transmission, approximately $10 \%$ of HIV-infected patients worldwide are chronically coinfected with HBV. Additionally, liver disease has become a major cause of morbidity and mortality in HBV/HIV coinfected patients due to prolonged survival with the success of antiretroviral therapy. The relationship between immune exhaustion markers (PD-1/PD-L1) and apoptotic markers such as Fas/ FasL, TGF $\beta 1$, TNF- $\alpha$, and Th1/Th2 cytokines are not clearly delineated in HBV/HIV coinfection.

Methods: Levels of soluble Fas/FasL, TGF $\beta 1$, TNF- $\alpha$, and sPD-1/sPD-L1 as well as Th1 and Th2 cytokines were evaluated in the sera of HBV-monoinfected $(n=30)$ and HBV/HIV-coinfected $(n=15)$ patients and compared to levels in healthy controls $(n=20)$.

Results: HBV-monoinfected patients had significantly lower levels of the anti-inflammatory cytokine IL-4 $(P<0.05)$ and higher levels of apoptotic markers sFas, sFasL, and TGF $\beta-1(P<0.001)$ compared to healthy controls. Coinfection with HIV was associated with higher levels of sFas, TNF- $\alpha$, and sPD-L1 $(P<0.005)$, and higher levels of the pro-inflammatory cytokines IL-6, IL-8, and IL-12p70 $(P<0.05)$ compared to healthy controls. Patients with HBV infection had a unique biomarker clustering profile comprised of IFN- $\gamma$, IL12p70, IL-10, IL-6, and TNF- $\alpha$ that was distinct from the profile of the healthy controls, and the unique HIV/HBV profile comprised GM-CSF, IL-4, IL-2, IFN- $\gamma$, IL12p70, IL-7, IL-10, and IL-1 $\beta$. In HBV monoinfection a significant correlation between sFasL and PD1 $(r=0.46, P=<0.05)$ and between sFas and PDL1 $(r=0.48$, $P=<0.01)$ was observed.

Conclusion: HBV-infected and HBV/HIV-coinfected patients have unique apoptosis and inflammatory biomarker profiles that distinguish them from each other and healthy controls. The utilization of those unique biomarker profiles for monitoring disease progression or identifying individuals who may benefit from novel immunotherapies such as anti-PD-L1 or anti-PD-1 checkpoint inhibitors appears promising and warrants further investigation.

Keywords: HBV; HIV; coinfection HBV/HIV; Immune exhaustion markers; sFas; PD-1; TNF- $\alpha$

\section{INTRODUCTION}

Hepatitis B virus (HBV) infection is a leading cause of chronic hepatitis, liver cirrhosis, and hepatocellular carcinoma (HCC) worldwide. It is estimated that 257 million people are infected with chronic HBV with approximately 3300 new cases per year in the United States alone. HBV is a non-cytopathic virus; therefore, liver damage-leading to fibrosis, cirrhosis, and HCC - is due to the immune response to viral infection $[\underline{1}, \underline{2}]$.

Due to their shared routes of transmission, HIV is common among patients infected with HBV. Approximately, 10\% of HIV-infected patients worldwide are thought to be coinfected with HBV. Additionally, liver disease has become a major cause of morbidity and mortality in HBV/HIV coinfected patients due to prolonged survival with success in antiretroviral therapy (ART) $[\underline{3}, \underline{4}]$.

The development of chronic HBV infection is influenced by several factors: (1) Exhausted or tolerant HBV-specific CD8+ T cells [ $\underline{5}, \underline{6}]$; (2) Suppressed CD4+ T-cell responsiveness mediated by dendritic cell impairment[7-9] or upregulation of PD-1 expression [1ㅇ, 11]; (3) Impaired innate 
immune responses through decreased natural killer cell function [12]; (4) Increased number of regulatory $\mathrm{T}$ cells $\left(\mathrm{T}_{\mathrm{reg}}\right)$ leading to suppression of HBV-specific T-cell responses and decreased viral clearance $[13,14]$; and (5) Induced apoptosis of Fas-expressing lymphocytes through activation of Fas/FasL pathways in Kupffer cells prompting immune tolerance to HBV and overcoming HBV clearance by the induced Fas/FasL apoptosis of hepatocytes [15].

Immune dysregulation is also thought to be a major factor leading to chronic HBV infection and the resulting liver diseases and carcinogenesis. A strong Th1-like immune response, characterized by high levels of functional cytolytic T lymphocytes (CTL), correlates with virus control and functional cures. A Th2-like inflammatory response is associated with viral persistence and progression of immunopathogenesis of $\operatorname{HBV}[\underline{16}, \underline{17}]$. The interactions among the different immunological pathways are complicated. For example, the pro-inflammatory cytokine IL- 8 has been shown to be a marker of liver damage and can also inhibit the antiviral activity of IFN- $\alpha$ [18-20]. TGF- $\beta 1$ is a major regulator of liver fibrosis; it can downregulate Th1 responses [21-26] and has been implicated in the development of HCC [27, 28]. Determining serum levels of cytokines and other immunoregulatory proteins may provide a measure to determine the likelihood of resolving an HBV infection or the risk of developing HCC.

In addition to the Th1/Th2 cytokine regulations, the PD-1/PD-L1 mechanism plays an important role in T-cell homeostasis, and it is involved in the regulation of anti-viral and anti-tumor immune response. PD-1 is expressed on both $\mathrm{T}$ and $\mathrm{B}$ cells in response to most immune challenges. The PD-1 protein is a negative regulator of T-cell activation [29]. The PD-1 signalling pathway is activated by binding PD-1 to its cognate receptors PD-L1 and/or PD-L2 [29, 30], which induces the inhibitory signal to impede the proliferation of $\mathrm{T}$ and $\mathrm{B}$ cells and to maintain peripheral tolerance $[\underline{29}, \underline{30}]$. On chronically stimulated Ag-specific T cells, PD-1 expression remains high, leading to an impaired response to stimuli. On hepatic T cells, PD-1 is expressed on the cell surface and is an important checkpoint molecule which can transduce co-inhibitory signals to immunocompetent cells and exert immunosuppressive roles. In addition to the membrane-bound PD-1 on T cells, there is a soluble PD-1 (sPD-1) [31] which is encoded by an alternative splice variant PD-1 Delta ex3 that lacks the transmembrane domain of the PD-1 molecule and can enhance anti-tumor immune responses [32-34]. In inflamed liver cytoplasmic expression of PD-L1 has been detected and may represent intracellular stores of PD-L1, which could be expressed upon proper stimulation on the cell surface or released in a soluble form into the microenvironment to suppress the anti-HBV immune responses [34-37]. PD-1 expression on CD8+ T cells correlates with viral load in patients with chronic HBV [38]. In vitro blocking of PD-1/PD-L1 interactions results in functional restoration of HBV-specific CD8+ T cells [39]. During HBV infection, higher levels of sPD-1 have been associated with immune tolerance and increased prevalence of HCC [40, 41] . These data suggest that monitoring sPD-1 or PD-L1 levels during infection may have prognostic value, and that PD-1 or PD-L1 may be an attractive target for restoring anti-HBV-specific T-cell responses in patients to either control or eradicate $\mathrm{HBV}$.

The Fas/FasL system also plays an important role in the regulation of the immune response to $\mathrm{HBV}$ in the liver and the apoptosis of infected hepatocytes. HBV-specific CD8 ${ }^{+} \mathrm{T}$ cells can kill $\mathrm{HBV}$-infected hepatocytes via the perforin/granzyme mechanism of killing or by the Fas/FasL mediated mechanism of killing. However, death of HBV-infected hepatocytes is thought to occur primarily through Fas-mediated killing. Soluble Fas (sFas) and soluble Fas ligand (sFasL) 
have been shown to inhibit hepatocyte apoptosis [42-44] allowing for the persistence of HBV in hepatocytes [45]. The Fas pathway is also involved in the apoptosis of activated T cells as a mechanism to maintain peripheral tolerance. A high level of Fas expression in HBV infected hepatocytes is thought to delete HBV-specific T cells leading to chronic infection and the development of HCC [46]. Interestingly, human HCC cell lines have been shown to be resistant to Fas-mediated apoptosis [47]. Soluble Fas and sFasL have much higher in cirrhosis and patients with HCC compared to normal controls [느].

In $\mathrm{HBV} / \mathrm{HIV}$-coinfected patients, there is acceleration of the immunologic and clinical progression of HIV infection with an increased risk of hepatotoxicity. Additionally, HIV infection increases the risk of hepatitis events, cirrhosis, and end-stage liver disease related to chronic HBV infection[48]. The immunological profiles associated with high morbidity in HBV/HIV coinfected patients are not fully understood. In this cross-sectional study we measured the serum levels of immunologic (Th1/Th2 and pro-inflammatory) cytokines and immunoregulatory proteins (sFasL, sFas, sPD-L1, and sPD-1) to test the hypothesis that their levels differ among individuals with chronic HBV or HIV/HBV coinfections and healthy controls.

\section{MATERIAL AND METHODS}

\section{Enrolled Patients}

Thirty HBV-monoinfected patients and $15 \mathrm{HBV} / \mathrm{HIV}$-coinfected patients from the University of Cincinnati Infectious Disease Center (UC IDC) and Hepatology clinics were previously evaluated in a retrospective study to determine HBV status [49]. To diagnose HBV, serological diagnoses of HBV infection (HBsAg) were detected by ELISA (BioChain, Hayward, CA). In some cases, HBV DNA was quantified using real-time PCR performed in triplicate and compared to a standard panel to determine viral titer (lower limit of detection [ [50] of $100 \mathrm{IU} / \mathrm{mL}$ ). To diagnose HIV, serological diagnoses of HIV were performed. When available, HIV RNA levels were determined by either qualitative or quantitative reverse transcriptase polymerase chain reactions (RT-PCR) obtained from clinical databases. Healthy controls were selected from volunteer lab workers with no history of HIV or HBV and negative serological markers for both HIV and HBV. Stored sera from healthy controls (20) were used as controls.

\section{Multiplex Assay}

The Human MILLIPLEX assay (EMD Millipore Corporation, Billerica, MA) was employed to measure serum concentrations of 13 immune markers: GM-CSF, IFN $\gamma$, IL-1 $\beta$, IL-2, IL-4, IL-5, IL-6, IL-7, IL-8, IL-10, IL-12 (p70), IL-13, TNF- $\alpha$, a 2-plex assay to measure apoptosis markers $s$ Fas and sFasL and a single-plex assay to measure TGF- $\beta 1$. Mean fluorescence intensity (MFI) analyte-specific signals were interpolated using standard curves and analyte concentrations were calculated using a 5-parameter logistic curve fitting algorithm on the Bio-Plex Manager 6.1.

Serum sPD-1 was measured using a sandwich ELISA assay (R\&D, Minneapolis, MN). Mean absorbance sPD-1 values were measured on a Biotek reader (Biotek, Winooski, VT) and sPD-1 concentrations $(\mathrm{pg} / \mathrm{mL})$ were calculated from a standard curve generated using a 4- parameter logistic curve fitting model. The dynamic range of the assay was 156 to $10,000 \mathrm{pg} / \mathrm{mL}$. 


\section{Soluble PD-L1 Assay}

An ECL immunoassay was used to measure the concentration of sPD-L1 in human serum using the MSD platform that has been previously described [51]. In brief, standards, controls, and test samples were incubated with biotinylated anti-PD-L1 capture antibody clone 2.7 A4 (MedImmune) that was immobilized on an MSD streptavidin-coated 96-well plate. After incubation, unbound material was washed away, and captured SPD-L1 was detected by addition of anti-PD-LI primary detection antibody clone 130021 (R\&D Systems). Unbound primary detection antibody was removed by washing. Bound primary detection antibody was detected by the addition of ruthenium-labeled secondary detection antibody (MSD), and the signal for each plate well was measured by an MSD Sector. The assay quantitation range was 15.6 to $1000 \mathrm{pg} / \mathrm{mL}$.

Concentrations below the lower limit of quantitation for all assays were assigned a value of onehalf the lower limit of the quantitation value for statistical comparisons. Samples with values greater than the upper limit of quantitation were further diluted, and dilution-corrected analyte concentrations were calculated accordingly.

\section{Statistical Analyses}

A general linear regression model was used to compare cytokine levels of individuals with disease to healthy controls adjusted for age, sex, and race effects. For each cytokine, to assess the difference between disease groups, the age, sex, and race were included in the model as covariates to evaluate potential effects on cytokine levels due to these covariates. If any of the covariates displayed statistical significance $(P$ value $\leq 0.05)$, the covariate would be included in the final general linear regression model, in addition to disease groups, to adjust for the effect due to covariates. The Spearman correlation coefficient was used to assess correlation between paired cytokine levels. The cluster analysis was applied to the correlation coefficient matrix to identify clusters of cytokines with average correlation coefficient values $\geq 0.55$. Statistical software packages including SAS 9.4 and R 3.4.3 were used for analysis.

\section{RESULTS}

\section{Characterization of Enrolled Individuals}

Demographics for the 30 patients with chronic HBV infection, the 15 with HBV/HIV coinfection and the 20 healthy controls are listed in Table 1. The average age for chronic HBV patients was 41.1 years, 45.1 years for $\mathrm{HBV} / \mathrm{HIV}$-coinfected patients, and 26.9 years for healthy controls. $\mathrm{Pa}$ tients who were HBV monoinfected and HBV/HIV coinfected were significantly $(P<0.001)$ older than the healthy controls. HBV-infected patients were predominantly Asian (40\%), while HBV/ HIV-coinfected patients and healthy controls were predominantly white (73\%, and 55\%, respectively). Median alanine aminotransferase (ALT) levels were $40 \mathrm{U} / \mathrm{L}$ in chronic $\mathrm{HBV}$ patients and 115.5 U/L in HBV/HIV-coinfected patients. Median aspartate transaminase (AST) levels were 29.5 U/L in chronic HBV patients and 109.5 U/L in HBV/HIV-coinfected patients. 
Table 1. Participant demographics

\begin{tabular}{|c|c|c|c|c|c|c|}
\hline Participants & $\begin{array}{c}\text { HBV Monoinfec- } \\
\text { tion } \\
\mathrm{N}=\mathbf{3 0}\end{array}$ & $\begin{array}{c}\text { HBV/HIV } \\
\text { Coinfection } \\
\text { N }=15\end{array}$ & $\begin{array}{c}\text { Healthy } \\
\text { Controls } \\
\mathrm{N}=20\end{array}$ & $\begin{array}{c}P \text { val- } \\
\text { ueHB- } \\
\text { V\&H- } \\
\text { BV/ } \\
\text { HIV }\end{array}$ & $\begin{array}{c}P \text { value } \\
\text { HB- } \\
\text { V\&HC }\end{array}$ & $\begin{array}{l}P \text { value } \\
\text { HC\& } \\
\text { HBV/ } \\
\text { HIV }\end{array}$ \\
\hline $\begin{array}{l}\text { Age } \\
(\text { Avg } \pm \text { STD }) \\
\text { Median (IQR) }\end{array}$ & $\begin{array}{r}41.1 \pm 14.95 \\
35(27.5) \\
\end{array}$ & $\begin{array}{r}45.1 \pm 7.9 \\
45(40) \\
\end{array}$ & $\begin{array}{r}26.9 \pm 6.1 \\
26(22) \\
\end{array}$ & NS & $<0.001$ & $<0.001$ \\
\hline \multicolumn{7}{|l|}{ Race } \\
\hline Black & 8 & 3 & 5 & & & \\
\hline White & 9 & 11 & 11 & & & \\
\hline Asian & 12 & 0 & 4 & & & \\
\hline Hispanic & 0 & 1 & 0 & & & \\
\hline $\begin{array}{l}\text { ALT U/L } \\
(\text { Avg } \pm \text { STD) } \\
\text { Median (IQR) }\end{array}$ & $\begin{array}{r}47.75 \pm 47.8 \\
40(23.25) \\
\end{array}$ & $\begin{array}{r}153.7 \pm 132.8 \\
115.5(59.25) \\
\end{array}$ & ND & $<0.01$ & $<0.01$ & $<0.01$ \\
\hline $\begin{array}{l}\text { AST U/L } \\
(\text { Avg } \pm \text { STD) } \\
\text { Median (IQR) }\end{array}$ & $\begin{array}{r}31.1 \pm 26.8 \\
29.5(21) \\
\end{array}$ & $\begin{array}{r}108.1 \pm 73.4 \\
109.5(41) \\
\end{array}$ & ND & $<0.01$ & $<0.01$ & $<0.01$ \\
\hline $\begin{array}{l}\text { HBV log copies/mL } \\
(\text { Avg } \pm \text { STD) } \\
\text { Median (IQR) }\end{array}$ & $\begin{array}{r}4.98 \pm 2.3 \\
4.65(3.46) \\
\end{array}$ & $\begin{array}{l}6.4 \pm 1.2 \\
6.47(5.3) \\
\end{array}$ & ND & NS & ND & ND \\
\hline $\begin{array}{l}{ }^{*} \% \text { of patient with } \\
\text { Cirrhosis }\end{array}$ & $25 \%$ & $25 \%$ & 0 & NS & ND & ND \\
\hline $\begin{array}{l}\text { HIV log copies/mL } \\
(\text { Avg } \pm \text { STD) } \\
\text { Median (IQR) }\end{array}$ & NA & $\begin{array}{r}6501 \pm 9369 \\
4440(2.7)\end{array}$ & ND & ND & ND & ND \\
\hline $\begin{array}{l}\% \text { of patients with } \\
\text { detectable HIV }\end{array}$ & NA & $91 \%$ & ND & $\mathrm{ND}$ & ND & $\mathrm{ND}$ \\
\hline $\begin{array}{l}\text { CD4 count } \\
(\text { Avg } \pm \text { STD }) \\
\text { Median, IQR }\end{array}$ & ND & $\begin{array}{l}536 \pm 285 \\
520(236) \\
\end{array}$ & ND & ND & ND & ND \\
\hline
\end{tabular}

$\mathrm{ND}=$ not done, $\mathrm{NS}=$ Not significant

${ }^{*}$ AST/ALT ratio (AAR) was used as marker of cirrhosis $(>1)$ for the enrolled subjects

ALT and AST were significantly higher $(P<0.01)$ in HBV/HIV-coinfected patients compared to those with HBV monoinfection, and compared to the normal levels for ALT (10-40 U/L) and AST (10-34 U/L). At the time of serum sample collection, HIV RNA was detectable by either a qualitative or a quantitative assay in 10 of $11(91 \%) \mathrm{HBV} / \mathrm{HIV}$-coinfected patients tested, and 
below the levels of detection in 1 (9\%) of the HBV/HIV patients tested. Among the HBV/HIV individuals with quantitative HIV viral loads, the median HIV RNA level was $4.4 \times 10^{3}$ copies $/ \mathrm{mL}$. CD 4 counts were available for 8 of 15 coinfected patients, with an average of $536 \pm 285.85$. No significant differences were observed between HIV-controlled and HIV-uncontrolled patients or the types of treatment. We utilized the AST/ALT ratio (AAR) as a marker of cirrhosis $(>1)$ for the enrolled patients $[\underline{50}, \underline{52-55}]$. For those with HBV alone, 4 of 16 had indications of cirrhosis, and 3 of 12 of the coinfected group had indications of cirrhosis. At the time of sample collection, only $15 \%$ of those with HBV monoinfection were receiving anti-HBV therapy, and 60\% of those with $\mathrm{HBV} / \mathrm{HIV}$ coinfection were receiving antiretroviral therapy containing anti-HBV-active agents. The average HBV DNA level was not significantly different among persons with HBV monoinfection, $4.98 \times 10^{3} \pm 2.3 \times 10^{3} \mathrm{IU} / \mathrm{mL}$, compared to $6.4 \times 10^{3} \pm 1.2 \times 10^{3} \mathrm{IU} / \mathrm{mL}$ among persons with $\mathrm{HBV} / \mathrm{HIV}$ coinfection.

\section{Distinct Serum Biomarker Profiles in HBV Versus HBV/HIV Infected Individuals}

To determine whether serum cytokine and inflammatory biomarker levels were different between $\mathrm{HBV}$ - and $\mathrm{HBV} / \mathrm{HIV}$-infected patients compared to one another and to healthy controls we tested the sera in a multiplex cytokine panel assay, an sPD-1 ELISA, and a proprietary ECLbased SPD-L1 assay (Table 2). Since there were differences in age, gender, and race between the 3 groups, a statistical model was developed to determine if the biomarker levels were different between the groups when adjusting for the covariates. The fold-differences between patients with $\mathrm{HBV}$ and controls and patients with $\mathrm{HBV} / \mathrm{HIV}$ and controls and the $95 \%$ confidence intervals are shown in Figure 1. Comparing the fold-differences of the geometric means of the various biomarkers in the individuals with $\mathrm{HBV}$ or $\mathrm{HBV} / \mathrm{HIV}$ to the healthy controls revealed statistically lower levels of IL-4 $(P=0.036)$ and significantly higher levels of apoptotic markers such as sFas, sFasL, and TGF $\beta-1(P<0.001)$ for HBV-infected patients compared to healthy controls (Figure 1$)$. Coinfection with HIV was associated with higher levels of sFas, TNF- $\alpha$, and sPD-L1 compared to healthy controls $(P<0.005)$. Additionally, multiple inflammatory cytokines including IL-6, IL-8, IL-10, IL-12p70 were significantly higher $(P<0.05)$ compared to controls (Figure 1). Interestingly, sFasL levels were much higher in HBV-monoinfected patients compared to healthy controls and HBV/HIV-infected patients (Figure 1). To adjust for covariates between groups including age, gender, and race, regression analyses for biomarkers with statistically significant differences less than $P=0.05$ were examined. Regression analysis determined that the only significant covariate was age for sFas levels but not for gender and race. To evaluate the relationship and the potential interactions among the biomarkers we examined the cluster correlation coefficient in the 3 groups. The cluster coefficient analyses revealed a distinct profile for $\mathrm{HBV}$ monoinfection with GM-CSF-IL4-IL2-IFN $\gamma$-IL12p70; IL-10- IL-6-TNF- $\alpha$ ) grouping together and a different, unique profile for HBV/HIV infection with (GM-CSF- IL-4- IL-2- IFN- $\gamma$ - IL12p70; IL-7- IL-10 -IL1- $\beta$ grouping together. The profiles of both $\mathrm{HBV}$ and $\mathrm{HBV} / \mathrm{HIV}$ patients are distinctly different from the profile of the healthy controls with IL10-PD-1; IL13-IL4-IL5- IL1b- IL2-GM-CSF- IFN- $\gamma$ IL12p70; IL-6- TNF- $a$ grouping together (Figure 2). In the group with HBV monoinfection a significant correlation between sFasL and PD1 $(r=0.46, P=<0.05)$ and between sFas and PDL1 $(\mathrm{r}=0.48, P=<0.01)$ was observed (Figure 1 and Supplementary Figure 1 ). 
Table 2. Geometric mean, standard deviation, and $P$ value for comparison of $\mathrm{HBV}$ mono-infected and HBV/HIV co-infected subjects to healthy controls

\begin{tabular}{|c|c|c|c|c|c|c|c|}
\hline \multirow[b]{2}{*}{ Cytokine } & \multirow{2}{*}{$\begin{array}{l}\text { Healthy Controls } \\
\qquad(\mathbf{N}=\mathbf{2 0}) \\
\text { Geometric Mean } \\
\text { (SD) }\end{array}$} & \multicolumn{3}{|c|}{$\begin{array}{l}\text { HBV Monoinfection } \\
\qquad(\mathrm{N}=\mathbf{3 0})\end{array}$} & \multicolumn{3}{|c|}{$\begin{array}{c}\text { HBV/HIV Coinfection } \\
(\mathrm{N}=15)\end{array}$} \\
\hline & & $\begin{array}{l}\text { Geometric } \\
\text { Mean (SD) }\end{array}$ & $P$-Value & q-Value ${ }^{a}$ & $\begin{array}{c}\text { Geometric Mean } \\
\text { (SD) }\end{array}$ & $P$-Value & q-Value ${ }^{a}$ \\
\hline GM-CSF & $142.6(224.8)$ & $94.6(69.5)$ & 0.7371 & 0.8420 & $120.3(127.5)$ & 0.4488 & 0.5814 \\
\hline IFN- $\gamma$ & $19.0(26.2)$ & $17.0(18.9)$ & 0.8026 & 0.8420 & $31.6(32.6)$ & 0.0783 & 0.2004 \\
\hline IL- $1 \beta$ & $3.8(3.6)$ & $3.9(4.1)$ & 0.9597 & 0.9597 & $3.2(3.0)$ & 0.5358 & 0.6430 \\
\hline IL-2 & $6.2(5.8)$ & $2.4(8.4)$ & 0.0801 & 0.2004 & $6.8(5.7)$ & 0.1863 & 0.3353 \\
\hline IL-4 & $12.0(29.8)$ & $4.2(22.7)$ & 0.0360 & 0.1178 & $10.2(18.5)$ & 0.7762 & 0.8420 \\
\hline IL-5 & $3.3(4.0)$ & $2.6(2.3)$ & 0.4522 & 0.5814 & $5.0(2.4)$ & 0.1702 & 0.3225 \\
\hline IL-6 & $3.1(2.0)$ & $3.8(2.7)$ & 0.4043 & 0.5800 & $5.4(3.0)$ & 0.0161 & 0.0680 \\
\hline IL-7 & $20.2(14.6)$ & $15.2(4.9)$ & 0.1315 & 0.2959 & $15.8(7.6)$ & 0.3448 & 0.5397 \\
\hline IL-8 & $12.6(6.5)$ & $15.6(17.2)$ & 0.1627 & 0.3225 & 25.7 (29.9) & 0.0052 & 0.0267 \\
\hline IL-10 & $9.8(9.7)$ & $13.2(14.7)$ & 0.0835 & 0.2004 & $16.5(21.8)$ & 0.032 & 0.1152 \\
\hline IL-12p70 & $6.0(6.0)$ & $6.4(4.8)$ & 0.8186 & 0.8420 & $12.0(5.7)$ & 0.017 & 0.0680 \\
\hline IL-13 & $7.7(7.4)$ & $6.7(11.8)$ & 0.8163 & 0.8420 & $7.7(5.9)$ & 0.2624 & 0.4498 \\
\hline TNF- $\alpha$ & $14.9(5.2)$ & $16.4(10.8)$ & 0.3878 & 0.5800 & $28.5(16.8)$ & $<.0001$ & $<.0001$ \\
\hline sFas & $7,114.2(2682.4)$ & $\begin{array}{l}10,129.1 \\
(3511.4) \\
\end{array}$ & $<.0001$ & $<.0001$ & $18,384.1(9775.4)$ & $<.0001$ & $<.0001$ \\
\hline sFasL & $9.2(76.7)$ & $73.2(29.1)$ & $<.0001$ & $<.0001$ & $7.0(10.9)$ & 0.3412 & 0.5397 \\
\hline TGF- $\beta 1$ & $22,135.1(7,812.3)$ & $\begin{array}{l}34,987.2 \\
(7331.2)\end{array}$ & $<.0001$ & $<.0001$ & $16,992.7(7756.2)$ & 0.4189 & 0.5800 \\
\hline sPD-1 & $389.9(2569.2)$ & $862.7(3972.1)$ & 0.169 & 0.3225 & $264.5(2308.1)$ & 0.5087 & 0.6315 \\
\hline sPD-L1 & $176.3(104.7)$ & $234.5(232.8)$ & 0.0652 & 0.1956 & $366.4(367.1)$ & 0.0025 & 0.0150 \\
\hline
\end{tabular}

${ }^{\mathrm{a}} \mathrm{q}$-value is for false discovery rate adjusted $P$ value 


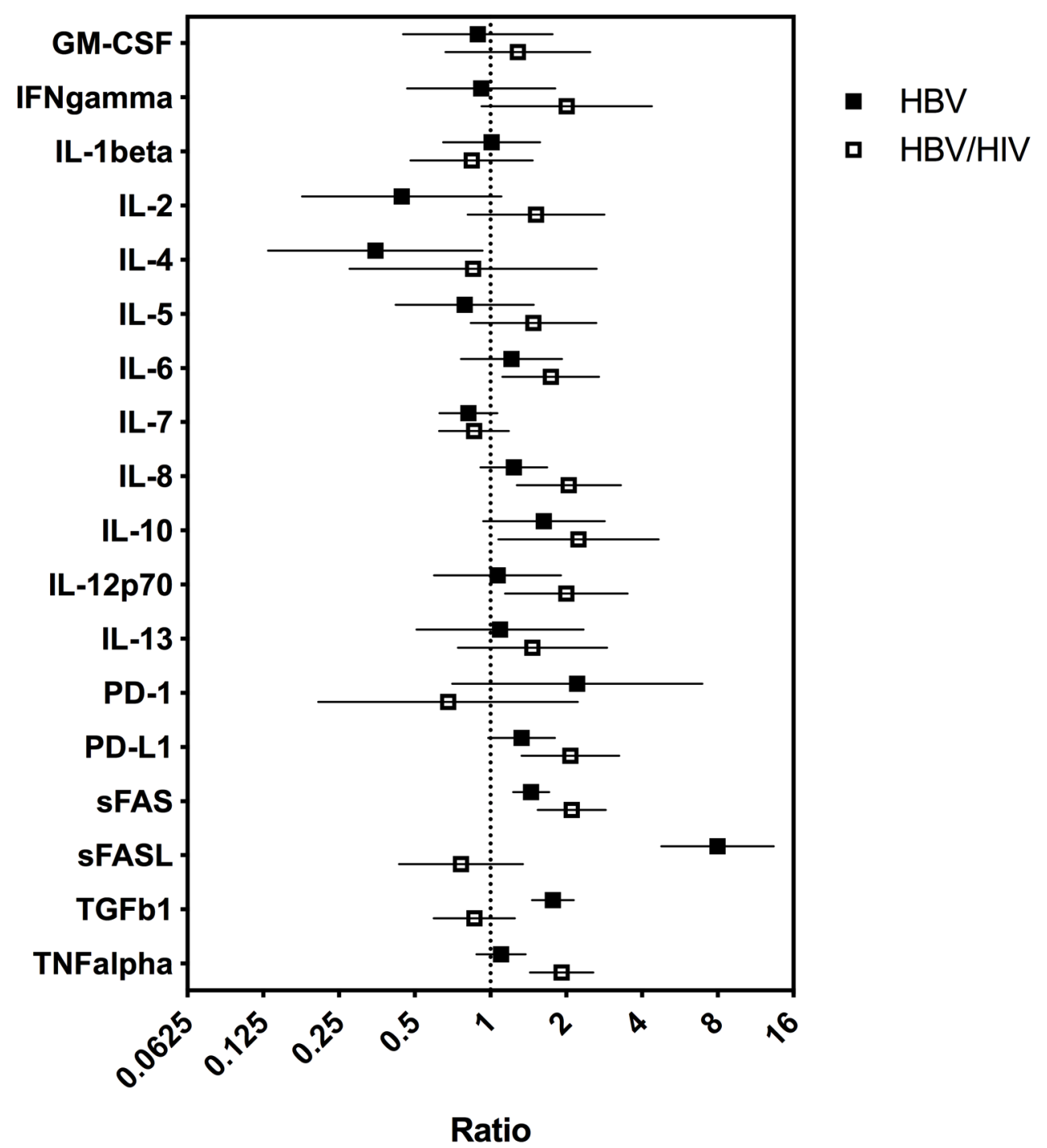

Figure 1. Fold-differences in biomarker values between $\mathrm{HBV}$ - and $\mathrm{HBV} / \mathrm{HIV}$-infected patients relative to healthy controls. Difference from healthy control is statistically significant if 95\% CI does not cross " 1 ". Analysis adjusted for covariates including age, gender, and race when effects of covariates were statistically significant $(P<0.05)$. 


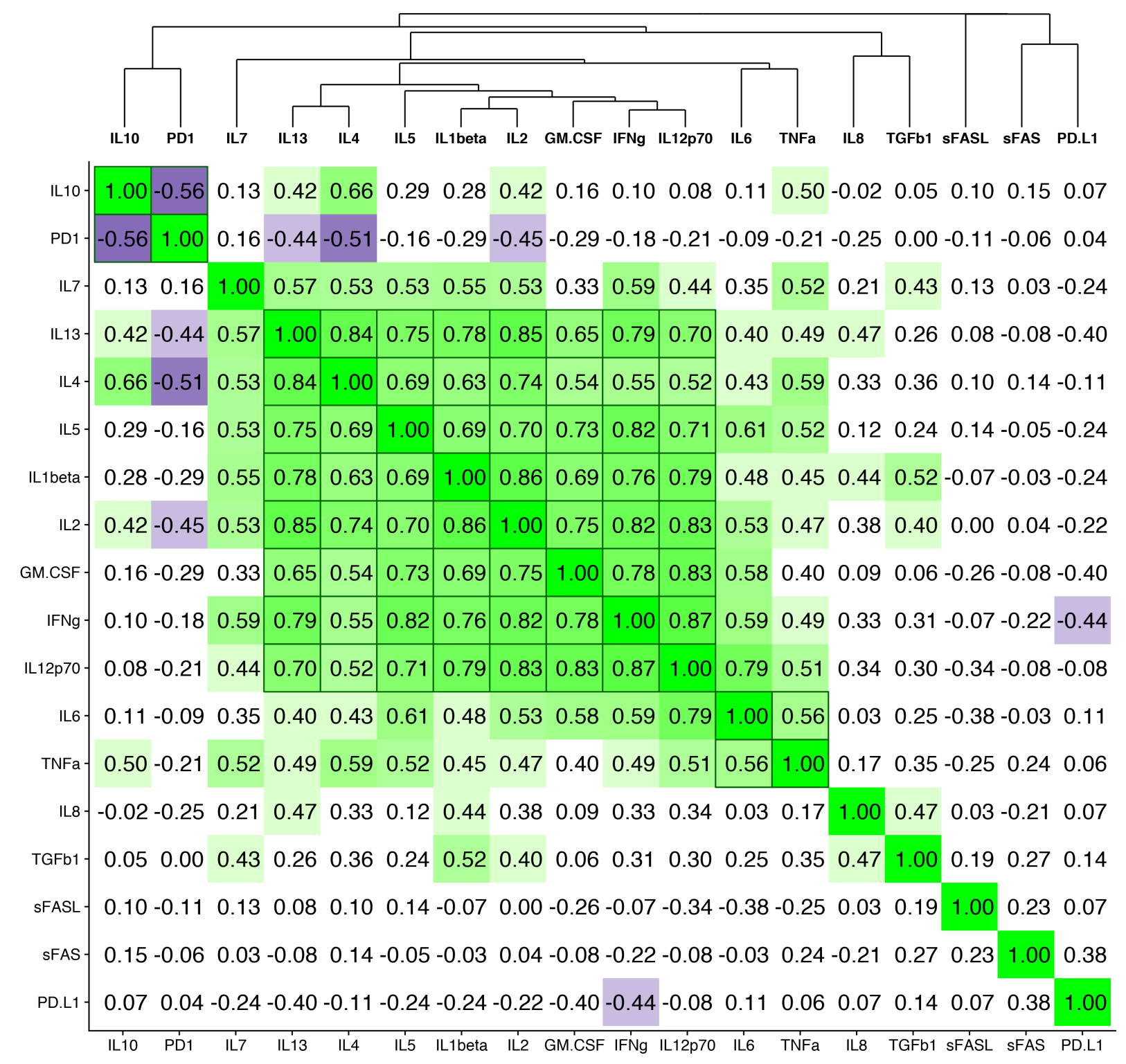

Figure 2A) Healthy Controls 


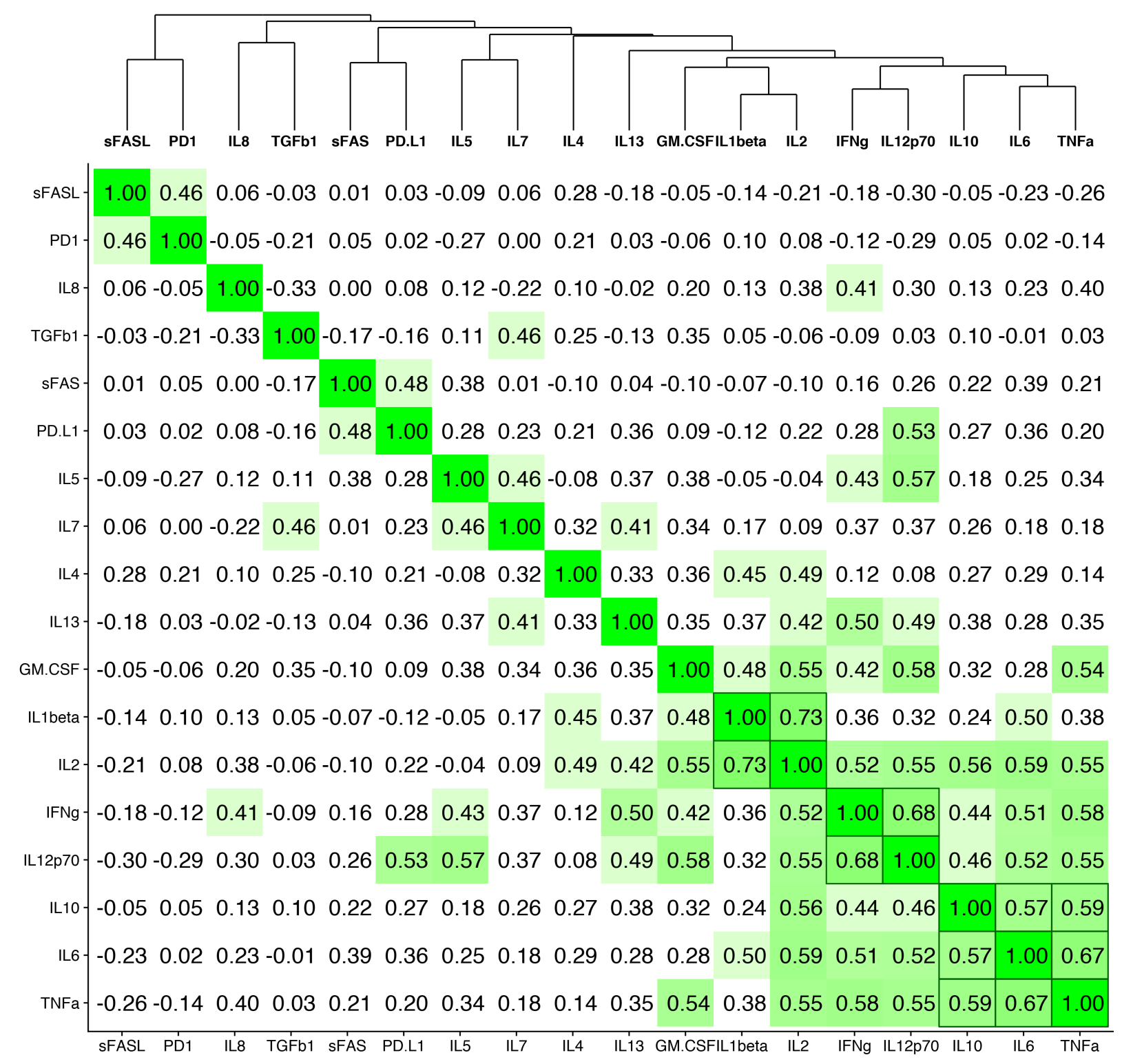

Figure 2B) HBV monoinfection 


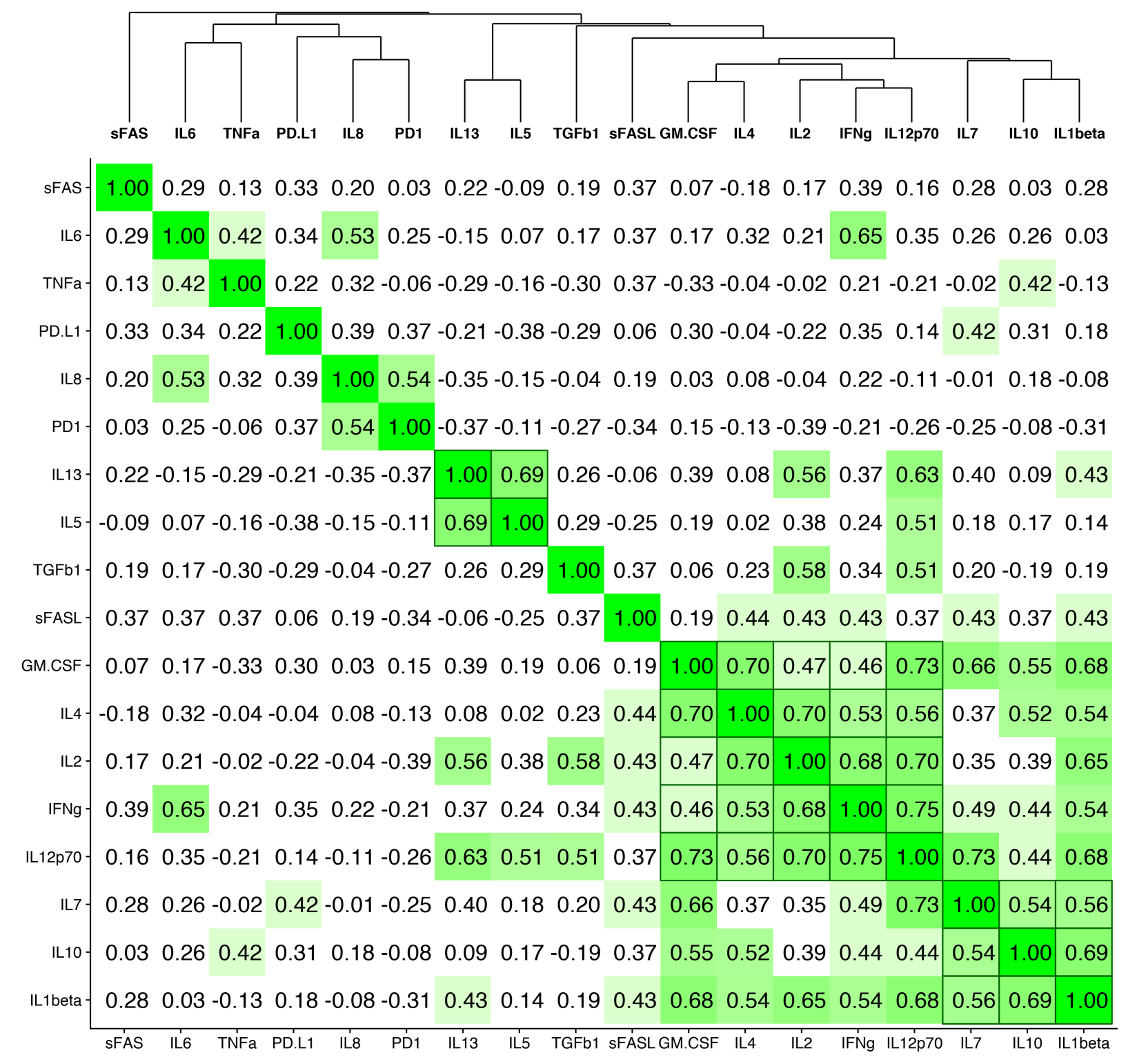

C) HBV and HIV coinfection

Figure 2. Cluster correlation biomarker profiles. Correlation coefficients of the immune and apoptotic biomarkers are shown for (A) healthy controls, (B) HBV-monoinfected patients and (C) HBV/HIV-coinfected patients.

\section{Correlation Among Clinical Parameters and Immunological Markers}

There are no significant correlations among HBV levels, HIV levels, CD4 counts, presence of cirrhosis, and the different immunological markers tested. However, there are significant positive correlations between ALT levels and IL-4 $(P=0.04, \mathrm{r}=0.39)$ and TNFa $(P=0.009, \mathrm{r}=0.48)$, and significant negative correlations with TGF- $\beta(P=0.007, \mathrm{r}=-0.49)$. Additionally, there are significant positive correlations between AST and IL-10 $(P=0.03, \mathrm{r}=0.41)$, IL-4 $(P=0.01, \mathrm{r}=0.47)$, 
IL-8 $(P=0.01, \mathrm{r}=0.48)$, and TNFa $(P=0.008, \mathrm{r}=0.59)$, and significant negative correlations with TGF- $\beta(P=0.0001, \mathrm{r}=-0.66)$.

\section{DISCUSSION}

In this cross-sectional study, we examined the serum immunological profiles and apoptotic markers of patients with HBV monoinfection $(n=30)$ or HBV/HIV coinfection $(n=15)$ and healthy controls $(n=20)$. Significantly higher levels $(P<0.001)$ of sFas (CD95; tumor necrosis factor receptor superfamily member 6, TNFR-SF6) were observed in the HBV and HBV/HIV- coinfected patients compared to the controls. Fas receptor is a member of the death receptor family, a subfamily of the tumor necrosis factor receptor superfamily. Fas is activated through oligomerization upon binding of FasL or the agonistic anti-Fas antibody. This causes formation of the death-inducing signaling complex (DISC), and the downstream activation of the death signal pathway, a cascade of interleukin-1 $\beta$-converting enzyme-like cysteine proteases [ㄷ6]. Fas-induced apoptosis is involved in the cytotoxic activity of T cells and natural killer cells [ㄷ7]. The Fas/FasL pathway plays an important role in controlling the local inflammatory response during viral infection [58]. Increasing evidence suggests that the Fas receptor is a mediator of apoptosis-independent processes such as induction of activating and pro-inflammatory signals [57-61]. Previous studies reported enhanced Fas system-mediated hepatocyte apoptosis in HIV-and HBV-associated chronic inflammation. In HBV viral hepatitis, liver-infiltrating lymphocytes that recognize the viral antigen on hepatocytes become activated and express FasL. In contrast, hepatocytes exhibit enhanced Fas expression and become susceptible to FasL-mediated death. Thus, Fas-mediated apoptosis plays an important role in HBV viral hepatitis and HIV infection [24, $\underline{62}, \underline{63}]$. It is interesting to note that the sFasL levels in HBV/HIV-coinfected patients were decreased in contrast to HBV infection (Figure 1 and Table 2). A previous study found a negative correlation between sFasL and $\mathrm{CD}^{+}$count in $\mathrm{HIV}$-infected patients [64]. Since FasL is mainly expressed on $\mathrm{CD}^{+} \mathrm{T}$ cells, and in those patients with HBV/HIV coinfection the numbers of CD4 ${ }^{+} \mathrm{T}$ cells are known to be lower than in those with HBV monoinfection or in healthy controls [ㄷ5], it is not surprising to see lower sFasL shed from exhausted and numerically decreased $\mathrm{CD} 4^{+} \mathrm{T}$-cell populations. Moreover, the balance between expression of sFas and sFasL is complicated. For example, in juvenile Systemic lupus erythematosus, a distinct profile from adult SLE, there is increased sFas and reduced sFasL, notably in patients with active disease and with nephritis [66]. Additionally, Pinti et al, reported an increase in the production of Fas with age [67], while the production of sFasL is consistently reduced [67] and suggested a dissociation between the levels of sFas and sFasL. Further longitudinal studies are warranted in $\mathrm{HBV}$-and HBV/HIV-infected patients to better understand the role sFas and sFasL are playing in HBV-mediated liver disease and whether there is any prognostic value in monitoring sFas and sFasL levels $[\underline{46}, \underline{62}, \underline{68}]$.

Soluble PD-L1 was similarly significantly $(P<0.005)$ higher in HBV/HIV coinfection compared to controls (Figure 1 and Table 2). In chronic viral infection, including HBV and HIV, persistent exposure to high concentrations of viral antigens leads to T-cell exhaustion. PD-1/PD-L1 interaction plays a critical role in T-cell exhaustion $[\underline{69}, \underline{70}]$. In HBV infection, PD-1 expression on T cells correlates with viral load [ $\underline{38}$ ] and PD-L1 expressed on infected hepatocytes [71-74]. In addition to membrane-bound PD1 and PD-L1, there are circulating soluble PD-1 (sPD-1)[31] and soluble PD-L1 (sPD-L1) [75, 76]. Several lines of evidence implicate a role for the soluble forms in regulating the $\mathrm{PD}-1 / \mathrm{PD}-\mathrm{L} 1$ pathways $[\underline{77}, \underline{78}]$. 
In chronic viral infection, viral-specific T-cell reactivity is weak or absent (exhausted immune response) and characterized by poor cytotoxic activity, impaired Th1 cytokine production, and sustained expression of multiple inhibitory receptors, such as PD-1 $[\underline{72}, \underline{79}, \underline{80}]$. Many studies have validated the existence of T-cell exhaustion in chronic viral diseases [79-81] and cancers $[\underline{82}, \underline{83}]$. Blocking of the inhibitory receptors with their ligands leads to the development of more effective immune responses. For example, PD-1 blockade has already been proven to restore the functional activity of HCV-specific $[\underline{84}, \underline{85}]$ and HIV [ [66]-specific CD8 ${ }^{+} \mathrm{T}$ cells and improved the immunological control of tumors in humans [7]. PD-1 blockade can increase IFN- $\gamma$ production in cells derived from HBV-monoinfected and HBV/HIV-coinfected patients as well [요].

There is accumulating evidence of a complicated interplay between the Fas/FasL pathway and PD-1/PD-L1 pathways. For instance, the neutralizing antibodies to PD-L1 and FasL significantly reduced the suppressive effect on T-cell proliferation [이. However, only anti-PD-L1 antibody partially restored early T-cell activation. Anti-FasL antibody, but not anti-PD-L1 antibody, reduced apoptosis of activated $\mathrm{T}$ cells indicating that FasL molecule plays a role in inducing apoptosis of activated T cells. Therefore, the presence of different effects of PD-L1 and FasL molecules on T-cell activation and apoptosis of activated T cells suggests that these 2 molecules influence T-cell responses at different stages [울. Only in the group with HBV monoinfection was a significant correlation observed between sFasL/PD1and sFas/PDL1. These data suggest that $\mathrm{HBV}$-monoinfected and $\mathrm{HBV} / \mathrm{HIV}$-infected patients have different biomarker profiles that may relate to different immune responses and disease pathogenesis processes.

TGF- $\beta 1$ was significantly higher in HBV monoinfection compared to healthy controls. TGF- $\beta$ plays a major immunological role during HBV viral infection through both direct and indirect mechanisms. TGF- $\beta$ directly stimulates hepatic stellate cells to synthesize and deliver extracellular matrix molecules such as collagens, fibronectin, and laminins within the stromal milieu [90]. There is also a strong cross talk among TGF- $\beta$ and the tissue extracellular matrix components. TGF- $\beta$ is stored in the matrix as part of a large latent complex bound to the latent TGF- $\beta$ binding protein (LTBP), and matrix binding of latent TGF- $\beta$ complexes is required for adequate TGF- $\beta$ function. Once TGF- $\beta$ is activated, it regulates extracellular matrix remodeling and promotes fibroblast to myofibroblast transition, which is essential in fibrotic processes. Therefore, within the liver, TGF- $\beta$ is pro-fibrogenic. TGF- $\beta$ also exerts immunosuppressive activity by inhibiting the host immune response. It is released by T cells, and it inhibits the secretion of TNF- $\alpha$, IFN- $\gamma$, and other interleukins [91]. It also serves as a differentiation factor for T-regulatory cells [92], and its increase may be playing a significant role in the reduction of inflammation within the liver. The significant positive correlations between ALT and AST with TNFa and the significant negative correlations with TGF- $\beta$ suggested a distinct role for each of those 2 cytokines in liver inflammation.

To evaluate the relationship and the potential interactions among the immunological biomarkers we examined the cluster correlation coefficient of the tested markers in the groups with $\mathrm{HBV}, \mathrm{HBV} / \mathrm{HIV}$ coinfection, and in healthy controls. The cluster coefficient profile analyses revealed distinct profiles for each group. In HBV monoinfection, IFN- $\gamma$-IL-2; IL12p70- IL-10IL-6- TNF- $\alpha$; and GM-CSF-IL1 $\beta$ are clustered together (Figure $2 \mathrm{~B}$ ). In contrast, the HBV/HIV coinfection group has a different unique profile with GM-CSF-IL-4- IL-2-IFN- $\gamma$-IL12p70; and IL-7-IL-10 -IL1- $\beta$ grouping together (Figure 2C). The control group also has a unique profile with 
IL-10-sPD-1; IL-13- IL4-IL5-IL-1 $\beta$-IL2-GM-CSF-IFN $\gamma$-IL12P70, and IL6-TNF $\alpha$ all grouping together (Figure $2 \mathrm{~A})$.

Cluster correlation of the apoptotic and exhaustion markers in the sera of the enrolled patients identified at least 2 independent apoptotic pathways. The first involved PD-1/PD-L1 and both FasL and TGF $\beta$ pathways. The second involved Fas and TNFa. The complex interaction between those 2 different pathways in HBV and HIV will be investigated in future studies.

The presence of unique biomarker profiles for each group is notable. The utilization of those unique biomarker profiles for disease progression is promising and will need further investigation. Additionally, the association of high levels of sPD-L1 and sFas with HBV infection suggests that targeting the PD-L1/PD-1 and/or Fas/FasL molecules in HBV-infected patients may be of therapeutic benefit in boosting the immune responses against HBV leading to viral clearance and/ or functional cure.

One of the limitations of our study, is its cross-sectional design. Furthermore, we did not have PBMCs or follow-up samples from the enrolled patients. Additionally, the number of studied individuals is relatively small, and the control group was not matched to $\mathrm{HBV}$ and $\mathrm{HBV} / \mathrm{HIV}$ groups for age and race. However, this descriptive study will be followed with a longitudinal study to test unresolved hypotheses.

In summary, HBV-infected patients had a unique biomarker clustering profile comprising IFN- $\gamma$, IL12p70, IL-10, IL-6, and TNF- $\alpha$ that was distinct from the profile of the healthy controls and from those with HBV/HIV coinfection. Longitudinal evaluation that better characterizes these markers in patients during different immunologic stages of the HBV natural history appear warranted.

\section{FUNDING}

The work was partially supported by grant from Medimmune, and the National Institute of Allergy and Infectious Diseases of the National Institutes of Health under Award Number R01 AI065256-06-A1 (to K. E. S.) and was supported in part by NIH grant P30 DK078392 of the Digestive Diseases Research Core Center in Cincinnati.

\section{CONFLICT OF INTEREST}

No conflict of interest for Enass A. Abdel-hameed, and Mrs. Susan D. Rouster.

Drs. Li Yu, Meina Liang, Esther Song, Mark T. Esser are employees of Medimmune.

Dr. Norah Shire is an employee of AstraZeneca.

Dr. Mohamed Tarek M. Shata and Dr. Kenneth E. Sherman are associated editors of Pathogens and Immunity. 


\section{REFERENCES}

1. Chang JJ, Lewin SR. Immunopathogenesis of hepatitis B virus infection. Immunol Cell Biol. 2007;85(1):16-23. PubMed PMID: 17130898. doi: 10.1038/sj.icb.7100009

2. Isogawa M, Furuichi Y, Chisari FV. Oscillating CD8(+) T cell effector functions after antigen recognition in the liver. Immunity. 2005;23(1):53-63. PubMed PMID: 16039579. doi: 10.1016/j.immuni.2005.05.005

3. Thio CL, Seaberg EC, Skolasky R, Jr., Phair J, Visscher B, Munoz A, Thomas DL, Multicenter ACS. HIV-1, hepatitis B virus, and risk of liver-related mortality in the Multicenter Cohort Study (MACS). Lancet. 2002;360(9349):1921-6. PubMed PMID: 12493258.

4. Klein MB, Althoff KN, Jing Y, Lau B, Kitahata M, Lo Re V, 3rd, Kirk GD, Hull M, Kim HN, Sebastiani G, Moodie EE, Silverberg MJ, Sterling TR, Thorne JE, Cescon A, Napravnik S, Eron J, Gill MJ, Justice A, Peters MG, Goedert JJ, Mayor A, Thio CL, Cachay ER, Moore R, North American ACCoR, Design of Ie DEA, North American ACCoR, Design of Ie DEA. Risk of End-Stage Liver Disease in HIV-Viral Hepatitis Coinfected Persons in North America From the Early to Modern Antiretroviral Therapy Eras. Clin Infect Dis. 2016;63(9):1160-7. PubMed PMID: 27506682. Pubmed Central PMCID: PMC5064164. doi: 10.1093/cid/ciw531

5. Kakimi K, Isogawa M, Chung J, Sette A, Chisari FV. Immunogenicity and tolerogenicity of hepatitis B virus structural and nonstructural proteins: implications for immunotherapy of persistent viral infections. J Virol. 2002;76(17):8609-20. PubMed PMID: 12163580.

6. Reignat S, Webster GJ, Brown D, Ogg GS, King A, Seneviratne SL, Dusheiko G, Williams R, Maini MK, Bertoletti A. Escaping high viral load exhaustion: CD8 cells with altered tetramer binding in chronic hepatitis B virus infection. J Exp Med. 2002;195(9):1089-101. PubMed PMID: 11994415.

7. Xu D, Fu J, Jin L, Zhang H, Zhou C, Zou Z, Zhao JM, Zhang B, Shi M, Ding X, Tang Z, Fu YX, Wang FS. Circulating and liver resident CD4+CD25+ regulatory T cells actively influence the antiviral immune response and disease progression in patients with hepatitis B. J Immunol. 2006;177(1):739-47. PubMed PMID: 16785573.

8. Ferrari C, Penna A, Giuberti T, Tong MJ, Ribera E, Fiaccadori F, Chisari FV. Intrahepatic, nucleocapsid antigen-specific T cells in chronic active hepatitis B. J Immunol. 1987;139(6):2050-8. PubMed PMID: 2957446.

9. Shimizu Y, Guidotti LG, Fowler P, Chisari FV. Dendritic cell immunization breaks cytotoxic T lymphocyte tolerance in hepatitis B virus transgenic mice. J Immunol. 1998;161(9):4520-9. PubMed PMID: 9794377.

10. Li M, Sun XH, Zhu XJ, Jin SG, Zeng ZJ, Zhou ZH, Yu Z, Gao YQ. HBcAg induces PD-1 upregulation on CD4+T cells through activation of JNK, ERK and PI3K/AKT pathways in chronic hepatitis-B-infected patients. Lab Invest. 2012;92(2):295-304. PubMed PMID: 22042085. doi: 10.1038/labinvest.2011.157 
11. Liang XS, Zhou Y, Li CZ, Wan MB. Natural course of chronic hepatitis B is characterized by changing patterns of programmed death type-1 of CD8-positive T cells. World J Gastroenterol. 2010;16(5):618-24. PubMed PMID: 20128032. Pubmed Central PMCID: PMC2816276.

12. Chen Y, Sun R, Wu X, Cheng M, Wei H, Tian Z. CD4+CD25+ Regulatory T Cells Inhibit Natural Killer Cell Hepatocytotoxicity of Hepatitis B Virus Transgenic Mice via Membrane-Bound TGF-beta and OX40. J Innate Immun. 2016;8(1):30-42. PubMed PMID: 26067079. doi: 10.1159/000431150

13. Peng G, Li S, Wu W, Sun Z, Chen Y, Chen Z. Circulating CD4+ CD25+ regulatory T cells correlate with chronic hepatitis B infection. Immunology. 2008;123(1):5765. PubMed PMID: 17764450. Pubmed Central PMCID: PMC2433275. doi: 10.1111/j.1365-2567.2007.02691.x

14. Trehanpati N, Vyas AK. Immune Regulation by T Regulatory Cells in Hepatitis B Virus-Related Inflammation and Cancer. Scand J Immunol. 2017;85(3):175-81. PubMed PMID: 28109025. doi: 10.1111/sji.12524

15. Yuan F, Zhang W, Mu D, Gong J. Kupffer cells in immune activation and tolerance toward HBV/HCV infection. Adv Clin Exp Med. 2017;26(4):739-45. PubMed PMID: 28691411. doi: 10.17219/acem/62759

16. Li MH, Zhang D, Zhang L, Qu XJ, Lu Y, Shen G, Wu SL, Chang M, Liu RY, Hu LP, Hao HX, Hua WH, Song SJ, Wan G, Liu SA, Xie Y. Ratios of T-helper 2 Cells to T-helper 1 Cells and Cytokine Levels in Patients with Hepatitis B. Chin Med J (Engl). 2017;130(15):1810-5. PubMed PMID: 28748854. Pubmed Central PMCID: PMC5547833. doi: 10.4103/0366-6999.211541

17. Cao H, Zhang R, Zhang W. CTLA4 interferes with the HBVspecific T cell immune response (Review). Int J Mol Med. 2018;42(2):703-12. PubMed PMID: 29786112. Pubmed Central PMCID: PMC6034931. doi: 10.3892/ijmm.2018.3688

18. Khabar KS, Al-Zoghaibi F, Al-Ahdal MN, Murayama T, Dhalla M, Mukaida N, Taha M, Al-Sedairy ST, Siddiqui Y, Kessie G, Matsushima K. The alpha chemokine, interleukin 8, inhibits the antiviral action of interferon alpha. J Exp Med. 1997;186(7):1077-85. PubMed PMID: 9314556. Pubmed Central PMCID: PMC2199072.

19. Haga Y, Kanda T, Nakamoto S, Nakamura M, Sasaki R, Wu S, Yokosuka O. Interferon induces interleukin 8 and bone marrow stromal cell antigen 2 expression, inhibiting the production of hepatitis B virus surface antigen from human hepatocytes. Biochem Biophys Res Commun. 2017;486(3):858-63. PubMed PMID: 28363866. doi: 10.1016/j. bbrc.2017.03.150

20. Kim SS, Cho HJ, Won JH, Bae JI, Kang DR, Lee JD, Shin SJ, Lee KM, Yoo BM, Kim JK, Lee JH, Ahn SJ, Park JH, Cho SW, Cheong JY. Interleukin-8 level as a prognostic marker in patients with hepatitis B virus-associated hepatocellular carcinoma treated with transarterial chemoembolization. Cytokine. 2015;76(2):449-57. PubMed PMID: 26163999. doi: 10.1016/j.cyto.2015.07.001

21. Ye L, Kan F, Yan T, Cao J, Zhang L, Wu Z, Li W. Enhanced antiviral and antifibrotic effects of short hairpin RNAs targeting HBV and TGF-beta in HBV-persistent 
mice. Sci Rep. 2017;7(1):3860. PubMed PMID: 28634402. Pubmed Central PMCID: PMC5478661. doi: 10.1038/s41598-017-04170-1

22. Argentou N, Germanidis G, Hytiroglou P, Apostolou E, Vassiliadis T, Patsiaoura K, Sideras P, Germenis AE, Speletas M. TGF-beta signaling is activated in patients with chronic HBV infection and repressed by SMAD7 overexpression after successful antiviral treatment. Inflamm Res. 2016;65(5):355-65. PubMed PMID: 26856334. doi: 10.1007/s00011-016-0921-6

23. Li HY, Ju D, Zhang DW, Li H, Kong LM, Guo Y, Li C, Wang XL, Chen ZN, Bian H. Activation of TGF-beta1-CD147 positive feedback loop in hepatic stellate cells promotes liver fibrosis. Sci Rep. 2015;5:16552. PubMed PMID: 26559755. Pubmed Central PMCID: PMC4642271. doi: 10.1038/srep16552

24. Silva JL, De Deus DM, Moreira RC, de Morais CN, Coelho MR. The relationship between hepatitis B virus (HBV) load and levels of transforming growth factor beta 1 (TGF-beta1) and soluble Fas (sFas) in human immunodeficiency virus patients with occult HBV infection. Arch Virol. 2015;160(7):1801-4. PubMed PMID: 25990938. doi: $10.1007 / \mathrm{s} 00705-015-2445-8$

25. Mehmedovic A, Mesihovic R, Prnjavorac B, Vanis N, Vukobrat-Bijedic Z, Borovac N, Zubcevic N, Pilav A, Gornjakovic S, Kulo-Cesic A, Mujaric E, Saray A. Non-invasive liver fibrosis markers: use of serum levels of cytokines IL 1alpha and TGF ss 1 in management of chronic liver diseases. Med Glas (Zenica). 2013;10(1):20-7. PubMed PMID: 23348156.

26. Karimi-Googheri M, Daneshvar H, Nosratabadi R, Zare-Bidaki M, Hassanshahi G, Ebrahim M, Arababadi MK, Kennedy D. Important roles played by TGF-beta in hepatitis B infection. J Med Virol. 2014;86(1):102-8. PubMed PMID: 24009084. doi: 10.1002/jmv.23727

27. Dong ZZ, Yao DF, Yao M, Qiu LW, Zong L, Wu W, Wu XH, Yao DB, Meng XY. Clinical impact of plasma TGF-betal and circulating TGF-beta1 mRNA in diagnosis of hepatocellular carcinoma. Hepatobiliary Pancreat Dis Int. 2008;7(3):288-95. PubMed PMID: 18522884.

28. Falleti E, Fabris C, Toniutto P, Fontanini E, Cussigh A, Bitetto D, Fornasiere E, Avellini C, Minisini R, Pirisi M. TGF-betal genotypes in cirrhosis: relationship with the occurrence of liver cancer. Cytokine. 2008;44(2):256-61. PubMed PMID: 18809335. doi: 10.1016/j.cyto.2008.08.008

29. Nishimura H, Honjo T. PD-1: an inhibitory immunoreceptor involved in peripheral tolerance. Trends Immunol. 2001;22(5):265-8. PubMed PMID: 11323285.

30. Latchman Y, Wood CR, Chernova T, Chaudhary D, Borde M, Chernova I, Iwai Y, Long AJ, Brown JA, Nunes R, Greenfield EA, Bourque K, Boussiotis VA, Carter LL, Carreno BM, Malenkovich N, Nishimura H, Okazaki T, Honjo T, Sharpe AH, Freeman GJ. PD-L2 is a second ligand for PD-1 and inhibits T cell activation. Nat Immunol. 2001;2(3):261-8. PubMed PMID: 11224527. doi: 10.1038/85330

31. Wan B, Nie H, Liu A, Feng G, He D, Xu R, Zhang Q, Dong C, Zhang JZ. Aberrant regulation of synovial $\mathrm{T}$ cell activation by soluble costimulatory molecules in rheumatoid arthritis. J Immunol. 2006;177(12):8844-50. PubMed PMID: 17142787. 
32. Xiao H, Huang B, Yuan Y, Li D, Han LF, Liu Y, Gong W, Wu FH, Zhang GM, Feng ZH. Soluble PD-1 facilitates 4-1BBL-triggered antitumor immunity against murine H22 hepatocarcinoma in vivo. Clin Cancer Res. 2007;13(6):1823-30. PubMed PMID: 17325342. doi: 10.1158/1078-0432.CCR-06-2154

33. Shin SP, Seo HH, Shin JH, Park HB, Lim DP, Eom HS, Bae YS, Kim IH, Choi K, Lee SJ. Adenovirus expressing both thymidine kinase and soluble PD1 enhances antitumor immunity by strengthening CD8 T-cell response. Mol Ther. 2013;21(3):688-95. PubMed PMID: 23337984. Pubmed Central PMCID: PMC3589170. doi: 10.1038/ mt.2012.252

34. Shi XL, Mancham S, Hansen BE, de Knegt RJ, de Jonge J, van der Laan LJ, Rivadeneira F, Metselaar HJ, Kwekkeboom J. Counter-regulation of rejection activity against human liver grafts by donor PD-L1 and recipient PD-1 interaction. J Hepatol. 2016;64(6):1274-82. PubMed PMID: 26941095. doi: 10.1016/j.jhep.2016.02.034

35. Taube JM, Anders RA, Young GD, Xu H, Sharma R, McMiller TL, Chen S, Klein AP, Pardoll DM, Topalian SL, Chen L. Colocalization of inflammatory response with B7-h1 expression in human melanocytic lesions supports an adaptive resistance mechanism of immune escape. Sci Transl Med. 2012;4(127):127ra37. PubMed PMID: 22461641. Pubmed Central PMCID: PMC3568523. doi: 10.1126/scitranslmed.3003689

36. Frigola X, Inman BA, Krco CJ, Liu X, Harrington SM, Bulur PA, Dietz AB, Dong H, Kwon ED. Soluble B7-H1: differences in production between dendritic cells and T cells. Immunol Lett. 2012;142(1-2):78-82. PubMed PMID: 22138406. Pubmed Central PMCID: PMC3901160. doi: 10.1016/j.imlet.2011.11.001

37. Frigola X, Inman BA, Lohse CM, Krco CJ, Cheville JC, Thompson RH, Leibovich B, Blute ML, Dong H, Kwon ED. Identification of a soluble form of B7-H1 that retains immunosuppressive activity and is associated with aggressive renal cell carcinoma. Clin Cancer Res. 2011;17(7):1915-23. PubMed PMID: 21355078. Pubmed Central PMCID: PMC3241002. doi: 10.1158/1078-0432.CCR-10-0250

38. Evans A, Riva A, Cooksley H, Phillips S, Puranik S, Nathwani A, Brett S, Chokshi S, Naoumov NV. Programmed death 1 expression during antiviral treatment of chronic hepatitis B: Impact of hepatitis B e-antigen seroconversion. Hepatology. 2008;48(3):759-69. PubMed PMID: 18697210. doi: 10.1002/hep.22419

39. Fisicaro P, Valdatta C, Massari M, Loggi E, Biasini E, Sacchelli L, Cavallo MC, Silini EM, Andreone P, Missale G, Ferrari C. Antiviral intrahepatic T-cell responses can be restored by blocking programmed death-1 pathway in chronic hepatitis B. Gastroenterology. 2010;138(2):682-93, 93 e1-4. PubMed PMID: 19800335. doi: 10.1053/j. gastro.2009.09.052

40. Li Z, Li N, Li F, Zhou Z, Sang J, Chen Y, Han Q, Lv Y, Liu Z. Immune checkpoint proteins PD-1 and TIM-3 are both highly expressed in liver tissues and correlate with their gene polymorphisms in patients with HBV-related hepatocellular carcinoma. Medicine (Baltimore). 2016;95(52):e5749. PubMed PMID: 28033288. Pubmed Central PMCID: PMC5207584. doi: 10.1097/MD.0000000000005749 
41. Peng G, Li S, Wu W, Tan X, Chen Y, Chen Z. PD-1 upregulation is associated with HBV-specific T cell dysfunction in chronic hepatitis B patients. Mol Immunol. 2008;45(4):963-70. PubMed PMID: 17868872. doi: 10.1016/j.molimm.2007.07.038

42. Tsutsui H, Kayagaki N, Kuida K, Nakano H, Hayashi N, Takeda K, Matsui K, Kashiwamura S, Hada T, Akira S, Yagita H, Okamura H, Nakanishi K. Caspase-1-independent, Fas/Fas ligand-mediated IL-18 secretion from macrophages causes acute liver injury in mice. Immunity. 1999;11(3):359-67. PubMed PMID: 10514014.

43. He P, Zhang B, Liu D, Bian X, Li D, Wang Y, Sun G, Zhou G. Hepatitis B Virus X Protein Modulates Apoptosis in NRK-52E Cells and Activates Fas/FasL Through the MLK3-MKK7-JNK3 Signaling Pathway. Cell Physiol Biochem. 2016;39(4):1433-43. PubMed PMID: 27606894. doi: 10.1159/000447846

44. Zamani AG, Barlas IO, Durakbasi-Dursun G, Ural O, Erdal E, Yildirim MS. Evaluation of death pathway genes FAS and FASL polymorphisms in chronic HBV infection. Int J Immunogenet. 2013;40(6):482-7. PubMed PMID: 23560484. doi: 10.1111/iji.12056

45. Martin CM, Welge JA, Shire NJ, Shata MT, Sherman KE, Blackard JT. Cytokine expression during chronic versus occult hepatitis B virus infection in HIV co-infected individuals. Cytokine. 2009;47(3):194-8. PubMed PMID: 19625194. Pubmed Central PMCID: PMC3031085. doi: 10.1016/j.cyto.2009.06.005

46. Wang XZ, Chen XC, Chen YX, Zhang LJ, Li D, Chen FL, Chen ZX, Chen HY, Tao QM. Overexpression of HBxAg in hepatocellular carcinoma and its relationship with Fas/ FasL system. World J Gastroenterol. 2003;9(12):2671-5. PubMed PMID: 14669310. Pubmed Central PMCID: PMC4612029.

47. Natoli G, Ianni A, Costanzo A, De Petrillo G, Ilari I, Chirillo P, Balsano C, Levrero M. Resistance to Fas-mediated apoptosis in human hepatoma cells. Oncogene. 1995;11(6):1157-64. PubMed PMID: 7566976.

48. Singh KP, Crane M, Audsley J, Avihingsanon A, Sasadeusz J, Lewin SR. HIV-hepatitis B virus coinfection: epidemiology, pathogenesis, and treatment. Aids. 2017;31(15):2035-52. PubMed PMID: 28692539. Pubmed Central PMCID: PMC5661989. doi: 10.1097/QAD.0000000000001574

49. Shire NJ, Rouster SD, Stanford SD, Blackard JT, Martin CM, Fichtenbaum CJ, Sherman KE. The prevalence and significance of occult hepatitis B virus in a prospective cohort of HIV-infected patients. J Acquir Immune Defic Syndr. 2007;44(3):309-14. PubMed PMID: 17159656. doi: 10.1097/QAI.0b013e31802e29a9

50. Nyblom H, Berggren U, Balldin J, Olsson R. High AST/ALT ratio may indicate advanced alcoholic liver disease rather than heavy drinking. Alcohol Alcohol. 2004;39(4):336-9. PubMed PMID: 15208167. doi: 10.1093/alcalc/agh074

51. Antonia S, Goldberg SB, Balmanoukian A, Chaft JE, Sanborn RE, Gupta A, Narwal R, Steele K, Gu Y, Karakunnel JJ, Rizvi NA. Safety and antitumour activity of durvalumab plus tremelimumab in non-small cell lung cancer: a multicentre, phase $1 \mathrm{~b}$ study. Lancet Oncol. 2016;17(3):299-308. PubMed PMID: 26858122. Pubmed Central PMCID: PMC5500167. doi: 10.1016/S1470-2045(15)00544-6 
52. Park SY, Kang KH, Park JH, Lee JH, Cho CM, Tak WY, Kweon YO, Kim SK, Choi YH. [Clinical efficacy of AST/ALT ratio and platelet counts as predictors of degree of fibrosis in HBV infected patients without clinically evident liver cirrhosis]. Korean J Gastroenterol. 2004;43(4):246-51. PubMed PMID: 15100488.

53. Sebastiani G, Castera L, Halfon P, Pol S, Mangia A, Di Marco V, Pirisi M, Voiculescu M, Bourliere M, Alberti A. The impact of liver disease aetiology and the stages of hepatic fibrosis on the performance of non-invasive fibrosis biomarkers: an international study of 2411 cases. Aliment Pharmacol Ther. 2011;34(10):1202-16. PubMed PMID: 21981787. doi: 10.1111/j.1365-2036.2011.04861.X

54. Nyblom H, Nordlinder H, Olsson R. High aspartate to alanine aminotransferase ratio is an indicator of cirrhosis and poor outcome in patients with primary sclerosing cholangitis. Liver Int. 2007;27(5):694-9. PubMed PMID: 17498256. doi: 10.1111/j.14783231.2007.01471.x

55. Nyblom H, Bjornsson E, Simren M, Aldenborg F, Almer S, Olsson R. The AST/ALT ratio as an indicator of cirrhosis in patients with PBC. Liver Int. 2006;26(7):840-5. PubMed PMID: 16911467. doi: 10.1111/j.1478-3231.2006.01304.X

56. Ramaswamy M, Cleland SY, Cruz AC, Siegel RM. Many checkpoints on the road to cell death: regulation of Fas-FasL interactions and Fas signaling in peripheral immune responses. Results Probl Cell Differ. 2009;49:17-47. PubMed PMID: 19132321. Pubmed Central PMCID: PMC2825281. doi: 10.1007/400_2008_24

57. Davidson WF, Haudenschild C, Kwon J, Williams MS. T cell receptor ligation triggers novel nonapoptotic cell death pathways that are Fas-independent or Fas-dependent. J Immunol. 2002;169(11):6218-30. PubMed PMID: 12444127.

58. Bien K, Sobanska Z, Sokolowska J, Baska P, Nowak Z, Winnicka A, Krzyzowska M. A lack of Fas/FasL signalling leads to disturbances in the antiviral response during ectromelia virus infection. Arch Virol. 2016;161(4):913-28. PubMed PMID: 26780774. doi: 10.1007/s00705-015-2746-y

59. Krzyzowska M, Baska P, Grochowska A, Orlowski P, Nowak Z, Winnicka A. Fas/FasL pathway participates in resolution of mucosal inflammatory response early during HSV-2 infection. Immunobiology. 2014;219(1):64-77. PubMed PMID: 24028839. doi: 10.1016/j.imbio.2013.08.002

60. Krzyzowska M, Baska P, Orlowski P, Zdanowski R, Winnicka A, Eriksson K, Stankiewicz W. HSV-2 regulates monocyte inflammatory response via the Fas/FasL pathway. PLoS One. 2013;8(7):e70308. PubMed PMID: 23922974. Pubmed Central PMCID: PMC3726399. doi: 10.1371/journal.pone.0070308

61. Bien K, Sokolowska J, Baska P, Nowak Z, Stankiewicz W, Krzyzowska M. Fas/FasL pathway participates in regulation of antiviral and inflammatory response during mousepox infection of lungs. Mediators Inflamm. 2015;2015:281613. PubMed PMID: 25873756. Pubmed Central PMCID: PMC4385687. doi: 10.1155/2015/281613

62. Bortolami M, Kotsafti A, Cardin R, Farinati F. Fas / FasL system, IL-1beta expression and apoptosis in chronic HBV and HCV liver disease. J Viral Hepat. 2008;15(7):51522. PubMed PMID: 18331250. doi: 10.1111/j.1365-2893.2008.00974.x 
63. Hayashi N, Mita E. Fas system and apoptosis in viral hepatitis. J Gastroenterol Hepatol. 1997;12(9-10):S223-6. PubMed PMID: 9407341.

64. Ikomey GM, Okomo-Assoumou MC, Atashili J, Mesembe MT, Mukwele B, Lyonga E, Eyoh A, Ndumbe PM. Plasma concentrations of soluble Fas receptors (Fas) and Fas ligands (FasL) in relation to CD4+ cell counts in HIV-1 positive and negative patients in Yaounde, Cameroon. BMC Res Notes. 2012;5:322. PubMed PMID: 22726303. Pubmed Central PMCID: PMC3441351. doi: 10.1186/1756-0500-5-322

65. Olawumi HO, Olanrewaju DO, Shittu AO, Durotoye IA, Akande AA, Nyamngee A. Effect of Hepatitis B Virus Co-Infection on CD4 Cell Count and Liver Function of HIV Infected Patients. Ghana Med J. 2015;49(1):2-6. PubMed PMID: 26339077. Pubmed Central PMCID: PMC4549810.

66. Liphaus BL, Kiss MHB, Carrasco S, Palmeira P, Goldenstein-Schainberg C, Carneiro-Sampaio M. Increased serum sFas, sTRAIL, and reduced sFasL in juvenile-onset systemic lupus erythematosus. Clin Rheumatol. 2017;36(12):2847-52. PubMed PMID: 28378099. doi: 10.1007/s10067-017-3615-8

67. Pinti M, Troiano L, Nasi M, Monterastelli E, Moretti L, Bellodi C, Mazzacani A, Mussi C, Salvioli G, Cossarizza A. Development of real time PCR assays for the quantification of Fas and FasL mRNA levels in lymphocytes: studies on centenarians. Mech Ageing Dev. 2003;124(4):511-6. PubMed PMID: 12714260.

68. Chen J, Su XS, Jiang YF, Gong GZ, Zheng YH, Li GY. Transfection of apoptosis related gene Fas ligand in human hepatocellular carcinoma cells and its significance in apoptosis. World J Gastroenterol. 2005;11(17):2653-5. PubMed PMID: 15849828. Pubmed Central PMCID: PMC4305760.

69. Barber DL, Wherry EJ, Masopust D, Zhu B, Allison JP, Sharpe AH, Freeman GJ, Ahmed R. Restoring function in exhausted CD8 T cells during chronic viral infection. Nature. 2006;439(7077):682-7. PubMed PMID: 16382236. doi: 10.1038/nature04444

70. Velu V, Titanji K, Zhu B, Husain S, Pladevega A, Lai L, Vanderford TH, Chennareddi L, Silvestri G, Freeman GJ, Ahmed R, Amara RR. Enhancing SIV-specific immunity in vivo by PD-1 blockade. Nature. 2009;458(7235):206-10. PubMed PMID: 19078956. Pubmed Central PMCID: PMC2753387. doi: 10.1038/nature07662

71. Zeng Z, Shi F, Zhou L, Zhang MN, Chen Y, Chang XJ, Lu YY, Bai WL, Qu JH, Wang CP, Wang H, Lou M, Wang FS, Lv JY, Yang YP. Upregulation of circulating PD-L1/ PD-1 is associated with poor post-cryoablation prognosis in patients with HBV-related hepatocellular carcinoma. PLoS One. 2011;6(9):e23621. PubMed PMID: 21912640. Pubmed Central PMCID: PMC3164659. doi: 10.1371/journal.pone.0023621

72. Xie DY, Lin BL, Chen FJ, Deng H, Chong YT, Zhang XH, Gao ZL. [Programmed death-1 (PD-1) and PD-L1 expression during antiviral treatment of chronic hepatitis B]. Zhonghua Gan Zang Bing Za Zhi. 2010;18(9):646-50. PubMed PMID: 20943073. doi: 10.3760/cma.j.issn.1007-3418.2010.09.002

73. Balsitis S, Gali V, Mason PJ, Chaniewski S, Levine SM, Wichroski MJ, Feulner M, Song Y, Granaldi K, Loy JK, Thompson CM, Lesniak JA, Brockus C, Kishnani N, Menne S, Cockett MI, Iyer R, Mason SW, Tenney DJ. Safety and efficacy of anti-PD-L1 therapy 
in the woodchuck model of HBV infection. PLoS One. 2018;13(2):e0190058. PubMed PMID: 29444087. Pubmed Central PMCID: PMC5812555. doi: 10.1371/journal. pone. 0190058

74. Xie Z, Chen Y, Zhao S, Yang Z, Yao X, Guo S, Yang C, Fei L, Zeng X, Ni B, Wu Y. Intrahepatic PD-1/PD-L1 up-regulation closely correlates with inflammation and virus replication in patients with chronic HBV infection. Immunol Invest. 2009;38(7):62438. PubMed PMID: 19811426.

75. Kim HJ, Park S, Kim KJ, Seong J. Clinical significance of soluble programmed cell death ligand-1 (sPD-L1) in hepatocellular carcinoma patients treated with radiotherapy. Radiother Oncol. 2018. PubMed PMID: 29366520. doi: 10.1016/j.radonc.2017.11.027

76. Kruger S, Legenstein ML, Rosgen V, Haas M, Modest DP, Westphalen CB, Ormanns S, Kirchner T, Heinemann V, Holdenrieder S, Boeck S. Serum levels of soluble programmed death protein 1 (sPD-1) and soluble programmed death ligand 1 (sPD-L1) in advanced pancreatic cancer. Oncoimmunology. 2017;6(5):e1310358. PubMed PMID: 28638732. Pubmed Central PMCID: PMC5467983. doi: 10.1080/2162402X.2017.1310358

77. Chen Y, Li M, Liu J, Pan T, Zhou T, Liu Z, Tan R, Wang X, Tian L, Chen E, Qu H. sPD-L1 Expression is Associated with Immunosuppression and Infectious Complications in Patients with Acute Pancreatitis. Scand J Immunol. 2017;86(2):100-6. PubMed PMID: 28513984. doi: 10.1111/sji.12564

78. Finkelmeier F, Canli O, Tal A, Pleli T, Trojan J, Schmidt M, Kronenberger B, Zeuzem S, Piiper A, Greten FR, Waidmann O. High levels of the soluble programmed death-ligand (sPD-L1) identify hepatocellular carcinoma patients with a poor prognosis. Eur J Cancer. 2016;59:152-9. PubMed PMID: 27039170. doi: 10.1016/j.ejca.2016.03.002

79. Foldi J, Kozhaya L, McCarty B, Mwamzuka M, Marshed F, Ilmet T, Kilberg M, Kravietz A, Ahmed A, Borkowsky W, Unutmaz D, Khaitan A. HIV-Infected Children Have Elevated Levels of PD-1+ Memory CD4 T Cells With Low Proliferative Capacity and High Inflammatory Cytokine Effector Functions. J Infect Dis. 2017;216(6):641-50. PubMed PMID: 28934428. Pubmed Central PMCID: PMC5853680. doi: 10.1093/infdis/jix341

80. Xiao W, Jiang LF, Deng XZ, Zhu DY, Pei JP, Xu ML, Li BJ, Wang CJ, Zhang JH, Zhang Q, Zhou ZX, Ding WL, Xu XD, Yue M. PD-1/PD-L1 signal pathway participates in $\mathrm{HCV} F$ protein-induced T cell dysfunction in chronic HCV infection. Immunol Res. 2016;64(2):412-23. PubMed PMID: 26286967. doi: 10.1007/s12026-015-8680-y

81. Penaloza-MacMaster P, Kamphorst AO, Wieland A, Araki K, Iyer SS, West EE, O’Mara L, Yang S, Konieczny BT, Sharpe AH, Freeman GJ, Rudensky AY, Ahmed R. Interplay between regulatory T cells and PD-1 in modulating T cell exhaustion and viral control during chronic LCMV infection. J Exp Med. 2014;211(9):1905-18. PubMed PMID: 25113973. Pubmed Central PMCID: PMC4144726. doi: 10.1084/jem.20132577

82. Boxberg M, Steiger K, Lenze U, Rechl H, von Eisenhart-Rothe R, Wortler K, Weichert W, Langer R, Specht K. PD-L1 and PD-1 and characterization of tumor-in- 
filtrating lymphocytes in high grade sarcomas of soft tissue - prognostic implications and rationale for immunotherapy. Oncoimmunology. 2018;7(3):e1389366. PubMed PMID: 29399389. Pubmed Central PMCID: PMC5790346. doi: 10.1080/2162402X.2017.1389366

83. Mitteldorf C, Berisha A, Tronnier M, Pfaltz MC, Kempf W. PD-1 and PD-L1 in neoplastic cells and the tumor microenvironment of Merkel cell carcinoma. J Cutan Pathol. 2017;44(9):740-6. PubMed PMID: 28569410. doi: 10.1111/cup.12973

84. Nakamoto N, Kaplan DE, Coleclough J, Li Y, Valiga ME, Kaminski M, Shaked A, Olthoff K, Gostick E, Price DA, Freeman GJ, Wherry EJ, Chang KM. Functional restoration of HCV-specific CD8 T cells by PD-1 blockade is defined by PD-1 expression and compartmentalization. Gastroenterology. 2008;134(7):1927-37, 37 e1-2. PubMed PMID: 18549878. Pubmed Central PMCID: PMC2665722. doi: 10.1053/j. gastro.2008.02.033

85. Urbani S, Amadei B, Tola D, Pedrazzi G, Sacchelli L, Cavallo MC, Orlandini A, Missale G, Ferrari C. Restoration of HCV-specific T cell functions by PD-1/PD-L1 blockade in HCV infection: effect of viremia levels and antiviral treatment. J Hepatol. 2008;48(4):548-58. PubMed PMID: 18280607. doi: 10.1016/j.jhep.2007.12.014

86. Velu V, Shetty RD, Larsson M, Shankar EM. Role of PD-1 co-inhibitory pathway in HIV infection and potential therapeutic options. Retrovirology. 2015;12:14. PubMed PMID: 25756928. Pubmed Central PMCID: PMC4340294. doi: 10.1186/s12977-0150144-X

87. Gajewski TF, Corrales L, Williams J, Horton B, Sivan A, Spranger S. Cancer Immunotherapy Targets Based on Understanding the T Cell-Inflamed Versus Non-T Cell-Inflamed Tumor Microenvironment. Adv Exp Med Biol. 2017;1036:19-31. PubMed PMID: 29275462. doi: 10.1007/978-3-319-67577-0_2

88. Sherman AC, Trehanpati N, Daucher M, Davey RT, Masur H, Sarin SK, Kottilil S, Kohli A. Augmentation of hepatitis B virus-specific cellular immunity with programmed death receptor-1/programmed death receptor-L1 blockade in hepatitis B virus and $\mathrm{HIV} /$ hepatitis B virus coinfected patients treated with adefovir. AIDS Res Hum Retroviruses. 2013;29(4):665-72. PubMed PMID: 23259453. Pubmed Central PMCID: PMC3607907. doi: 10.1089/AID.2012.0320

89. Gu YZ, Xue Q, Chen YJ, Yu GH, Qing MD, Shen Y, Wang MY, Shi Q, Zhang XG. Different roles of PD-L1 and FasL in immunomodulation mediated by human placenta-derived mesenchymal stem cells. Hum Immunol. 2013;74(3):267-76. PubMed PMID: 23261407. doi: 10.1016/j.humimm.2012.12.011

90. Liu Y, Liu H, Meyer C, Li J, Nadalin S, Konigsrainer A, Weng H, Dooley S, ten Dijke P. Transforming growth factor-beta (TGF-beta)-mediated connective tissue growth factor (CTGF) expression in hepatic stellate cells requires Stat3 signaling activation. J Biol Chem. 2013;288(42):30708-19. PubMed PMID: 24005672. Pubmed Central PMCID: PMC3798541. doi: 10.1074/jbc.M113.478685 
91. Theron AJ, Anderson R, Rossouw TM, Steel HC. The Role of Transforming Growth Factor Beta-1 in the Progression of HIV/AIDS and Development of Non-AIDS-Defining Fibrotic Disorders. Front Immunol. 2017;8:1461. PubMed PMID: 29163528. Pubmed Central PMCID: 5673850. doi: 10.3389/fimmu.2017.01461

92. Becker C, Fantini MC, Neurath MF. TGF-beta as a T cell regulator in colitis and colon cancer. Cytokine Growth Factor Rev. 2006;17(1-2):97-106. PubMed PMID: 16298544. doi: 10.1016/j.cytogfr.2005.09.004

\section{SUPPLEMENTARY MATERIALS}

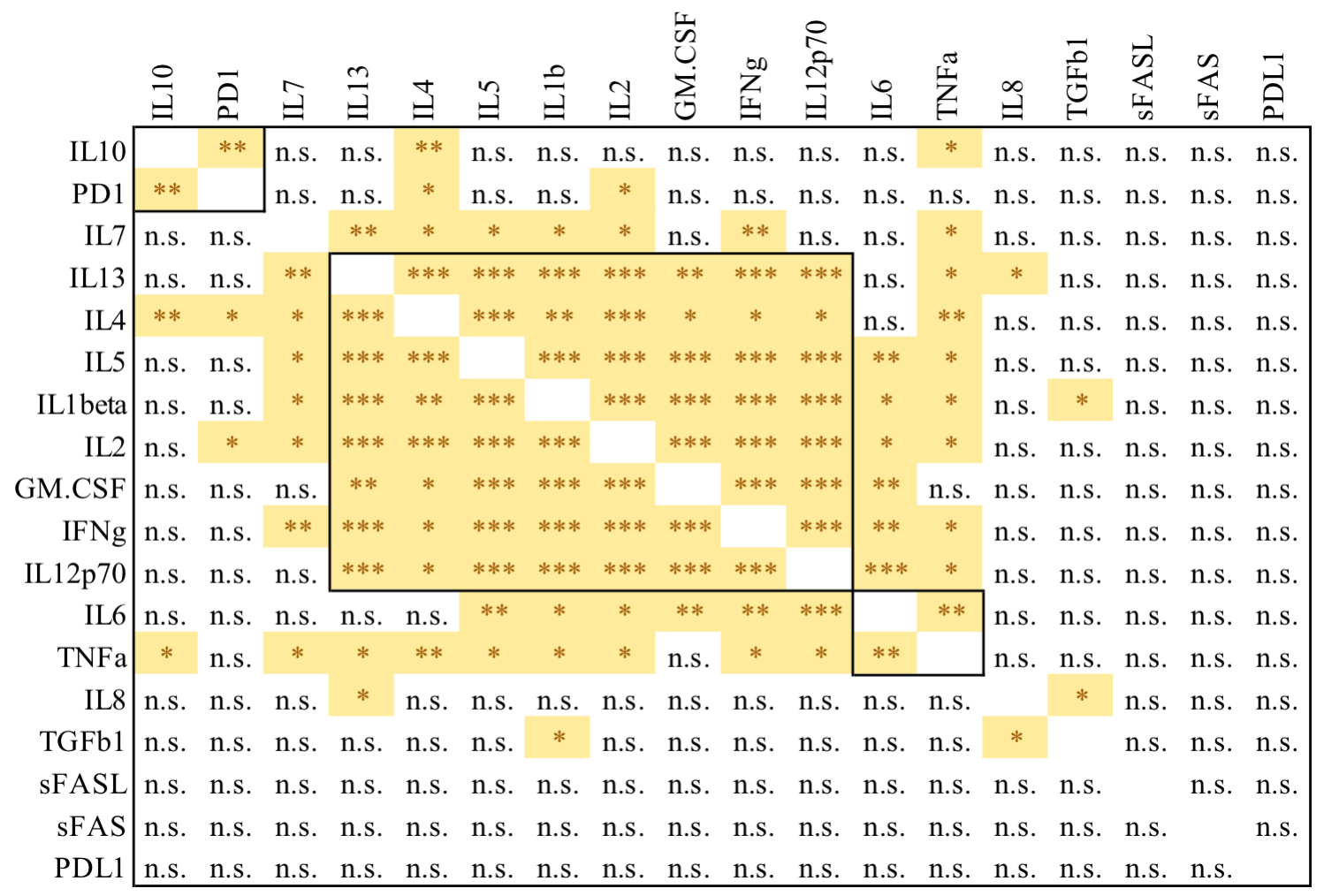

Supplementary Figure 1A) Healthy Controls 


\begin{tabular}{|c|c|c|c|c|c|c|c|c|c|c|c|c|c|c|c|c|c|c|}
\hline & $\underset{\pi}{\mathbb{S}}$ & $\overrightarrow{\mathrm{a}}$ & $\stackrel{\infty}{\ominus}$ & 可 & $\sum_{\frac{1}{\infty}}^{\infty}$ & $\vec{a}$ & 当 & 可 & 声 & $\stackrel{n}{\exists}$ & $\sum_{0}^{\infty}$ & 三 & త & $Z_{\Xi}^{\infty}$ & $\begin{array}{l}\stackrel{ }{2} \\
\text { ㄱ. } \\
\exists \\
=\end{array}$ & $\begin{array}{l}\circ \\
\exists\end{array}$ & $\stackrel{\varrho}{\ominus}$ & $\underset{⿱ 乛}{\stackrel{\sigma}{Z}}$ \\
\hline sFASL & & * & n.s. & n.s. & n.s. & n.s. & n.s. & n.s. & n.s. & n.s. & n.s. & n.s. & n.s. & n.s. & n.s. & n.s. & n.s. & n.s. \\
\hline PD1 & * & & n.s. & n.s. & n.s. & n.s. & n.s. & n.s. & n.s. & n.s. & n.s. & n.s. & n.s. & n.s. & n.s. & n.s. & n.s. & n.s. \\
\hline IL8 & n.s. & n.s. & & n.s. & n.s. & n.s. & n.s. & n.s. & n.s. & n.s. & n.s. & n.s. & $*$ & $*$ & n.s. & n.s. & n.s. & $*$ \\
\hline TGFbl & n.s. & n.s. & n.s. & & n.s. & n.s. & n.s. & * & n.s. & n.s. & n.s. & n.s. & n.s. & n.s. & n.s. & n.s. & n.s. & n.s. \\
\hline sFAS & n.s. & n.s. & n.s. & n.s. & & $* *$ & $*$ & n.s. & n.s. & n.s. & n.s. & n.s. & n.s. & n.s. & n.s. & n.s. & * & n.s. \\
\hline PDL1 & n.s. & n.s. & n.s. & n.s. & $* *$ & & n.s. & n.s. & n.s. & n.s. & n.s. & n.s. & n.s. & n.s. & $* *$ & n.s. & n.s. & n.s. \\
\hline IL5 & n.s. & n.s. & n.s. & n.s. & * & n.s. & & * & n.s. & * & $*$ & n.s. & n.s. & * & $* *$ & n.s. & n.s. & n.s. \\
\hline IL7 & n.s. & n.s. & n.s. & * & n.s. & n.s. & $*$ & & n.s. & $*$ & n.s. & n.s. & n.s. & $*$ & $*$ & n.s. & n.s. & n.s. \\
\hline IL4 & n.s. & n.s. & n.s. & n.s. & n.s. & n.s. & n.s. & n.s. & & n.s. & n.s. & * & $* *$ & n.s. & n.s. & n.s. & n.s. & n.s. \\
\hline IL13 & n.s. & n.s. & n.s. & n.s. & n.s. & n.s. & * & $*$ & n.s. & & n.s. & $*$ & * & $* *$ & $* *$ & * & n.s. & n.s. \\
\hline GM.CSF & n.s. & n.s. & n.s. & n.s. & n.s. & n.s. & $*$ & n.s. & n.s. & n.s. & & $* *$ & $* *$ & * & *** & n.s. & n.s. & $* *$ \\
\hline IL1b & n.s. & n.s. & n.s. & n.s. & n.s. & n.s. & n.s. & n.s. & * & $*$ & $* *$ & & $* * *$ & n.s. & n.s. & n.s. & $* *$ & $*$ \\
\hline IL2 & n.s. & n.s. & * & n.s. & n.s. & n.s. & n.s. & n.s. & $* *$ & * & $* *$ & $* * *$ & & $* *$ & $* *$ & $* *$ & $* * *$ & $* *$ \\
\hline IFNg & n.s. & n.s. & * & n.s. & n.s. & n.s. & * & * & n.s. & $* *$ & * & n.s. & $* *$ & & $* * *$ & $*$ & $* *$ & $* * *$ \\
\hline IL12p70 & n.s. & n.s. & n.s. & n.s. & n.s. & $* *$ & $* *$ & * & n.s. & $* *$ & $* * *$ & n.s. & $* *$ & $* * *$ & & $*$ & $* *$ & $* *$ \\
\hline IL10 & n.s. & n.s. & n.s. & n.s. & n.s. & n.s. & n.s. & n.s. & n.s. & * & n.s. & n.s. & $* *$ & * & $*$ & & $* *$ & $* * *$ \\
\hline IL6 & n.s. & n.s. & n.s. & n.s. & $*$ & n.s. & n.s. & n.s. & n.s. & n.s. & n.s. & $* *$ & $* * *$ & * & $*$ & $* *$ & & $* * *$ \\
\hline $\mathrm{TNFa}$ & n.s. & n.s. & $*$ & n.s. & n.s. & n.s. & n.s. & n.s. & n.s. & n.s. & $* *$ & $*$ & $* *$ & $* * *$ & $* *$ & $* * *$ & $* * *$ & \\
\hline
\end{tabular}

Supplementary Figure 1B) HBV monoinfection 


\begin{tabular}{|c|c|c|c|c|c|c|c|c|c|c|c|c|c|c|c|c|c|c|}
\hline & $\sum_{\pi}^{\infty}$ & $\stackrel{\bullet}{\ominus}$ & $\stackrel{\pi}{Z}$ & $\vec{a}$ & $\stackrel{\infty}{=}$ & $\hat{2}$ & $\stackrel{m}{\exists}$ & 当 & 定 & $\underset{\infty}{\infty}$ & $\sum_{0}^{\sqrt[U]{\sim}}$ & 声 & 코 & $Z^{\infty}$ & \begin{tabular}{l}
0 \\
\multirow{2}{2}{} \\
글
\end{tabular} & $\hat{\exists}$ & $\begin{array}{l}\circ \\
\exists \\
\end{array}$ & 三 \\
\hline sFAS & & n.s. & n.s. & n.s. & n.s. & n.s. & n.s. & n.s. & n.s. & n.s. & n.s. & n.s. & n.s. & n.s. & n.s. & n.s. & n.s. & n.s. \\
\hline IL6 & n.s. & & n.s. & n.s. & * & n.s. & n.s. & n.s. & n.s. & n.s. & n.s. & n.s. & n.s. & $* *$ & n.s. & n.s. & n.s. & n.s. \\
\hline $\mathrm{TNFa}$ & n.s. & n.s. & & n.s. & n.s. & n.s. & n.s. & n.s. & n.s. & n.s. & n.s. & n.s. & n.s. & n.s. & n.s. & n.s. & n.s. & n.s. \\
\hline PDL1 & n.s. & n.s. & n.s. & & n.s. & n.s. & n.s. & n.s. & n.s. & n.s. & n.s. & n.s. & n.s. & n.s. & n.s. & n.s. & n.s. & n.s. \\
\hline IL8 & n.s. & * & n.s. & n.s. & & * & n.s. & n.s. & n.s. & n.s. & n.s. & n.s. & n.s. & n.s. & n.s. & n.s. & n.s. & n.s. \\
\hline PD1 & n.s. & n.s. & n.s. & n.s. & * & & n.s. & n.s. & n.s. & n.s. & n.s. & n.s. & n.s. & n.s. & n.s. & n.s. & n.s. & n.s. \\
\hline IL13 & n.s. & n.s. & n.s. & n.s. & n.s. & n.s. & & $* *$ & n.s. & n.s. & n.s. & n.s. & * & n.s. & * & n.s. & n.s. & n.s. \\
\hline IL5 & n.s. & n.s. & n.s. & n.s. & n.s. & n.s. & $* *$ & & n.s. & n.s. & n.s. & n.s. & n.s. & n.s. & n.s. & n.s. & n.s. & n.s. \\
\hline TGFb1 & n.s. & n.s. & n.s. & n.s. & n.s. & n.s. & n.s. & n.s. & & n.s. & n.s. & n.s. & $*$ & n.s. & n.s. & n.s. & n.s. & n.s. \\
\hline sFASL & n.s. & n.s. & n.s. & n.s. & n.s. & n.s. & n.s. & n.s. & n.s. & & n.s. & n.s. & n.s. & n.s. & n.s. & n.s. & n.s. & n.s. \\
\hline M.CSF & n.s. & n.s. & n.s. & n.s. & n.s. & n.s. & n.s. & n.s. & n.s. & n.s. & & $* *$ & n.s. & n.s. & $* *$ & $* *$ & * & $* *$ \\
\hline IL4 & n.s. & n.s. & n.s. & n.s. & n.s. & n.s. & n.s. & n.s. & n.s. & n.s. & $* *$ & & $* *$ & $*$ & * & n.s. & * & $*$ \\
\hline IL2 & n.s. & n.s. & n.s. & n.s. & n.s. & n.s. & * & n.s. & $*$ & n.s. & n.s. & $* *$ & & $* *$ & $* *$ & n.s. & n.s. & $* *$ \\
\hline IFNg & n.s. & $* *$ & n.s. & n.s. & n.s. & n.s. & n.s. & n.s. & n.s. & n.s. & n.s. & * & $* *$ & & $* *$ & n.s. & n.s. & $*$ \\
\hline IL12p70 & n.s. & n.s. & n.s. & n.s. & n.s. & n.s. & $*$ & n.s. & n.s. & n.s. & $* *$ & $*$ & $* *$ & $* *$ & & $* *$ & n.s. & $* *$ \\
\hline IL7 & n.s. & n.s. & n.s. & n.s. & n.s. & n.s. & n.s. & n.s. & n.s. & n.s. & $* *$ & n.s. & n.s. & n.s. & $* *$ & & $*$ & $*$ \\
\hline IL10 & n.s. & n.s. & n.s. & n.s. & n.s. & n.s. & n.s. & n.s. & n.s. & n.s. & * & * & n.s. & n.s. & n.s. & * & & $* *$ \\
\hline IL1b & n.s. & n.s. & n.s. & n.s. & n.s. & n.s. & n.s. & n.s. & n.s. & n.s. & $* *$ & * & $* *$ & * & $* *$ & * & $* *$ & \\
\hline
\end{tabular}

C) HBV and HIV coinfection

Supplementary Figure 1. $P$ Values for Figure 2. Correlation coefficients $P$ values for biomarker levels are shown for (A) healthy controls, (B) HBV-monoinfected patients and (C) HBV/HIV-coinfected patients, $P$ value $<0.05\left(^{*}\right),<0.01\left(^{* *}\right),<0.001\left(^{* * *}\right),>0.05$ (n.s.)

\section{FOOTNOTES}

Submitted October 22, 2018 | Accepted January 23, 2019 | Published February 13, 2019

\section{COPYRIGHT}

Copyright (C) 2019 Pathogens and Immunity

This is an open-access article distributed under the terms of the Creative Commons Attribution 4.0 International License. 